HYDROGEOLOGY AND WATER QUALITY OF THE

CATOCTIN MOUNTAIN NATIONAL PARK AREA,

FREDERICK COUNTY, MARYLAND

By Thomas J. Trombley and Linda D. Zynjuk

U.S. GEOLOGICAL SURVEY

Water-Resources Investigations Report 85-4241

Prepared in cooperation with the

NATIONAL PARK SERVICE

Towson, Maryland 
UNITED STATES DEPARTMENT OF THE INTERIOR

DONALD PAUL HODEL, Secretary

GEOLOGICAL SURVEY

Dallas L. Peck, Director

For additional information write to:

District Chief

U.S. Geological Survey

208 Carroll Building

8600 La Salle Road

Towson, Maryland 21204
Copies of this report can be purchased from:

Open-File Services Section Western Distribution Branch U.S. Geological Survey Box 25425, Federal Center Denver, Colorado 80225 (Telephone: (303)234-5888) 


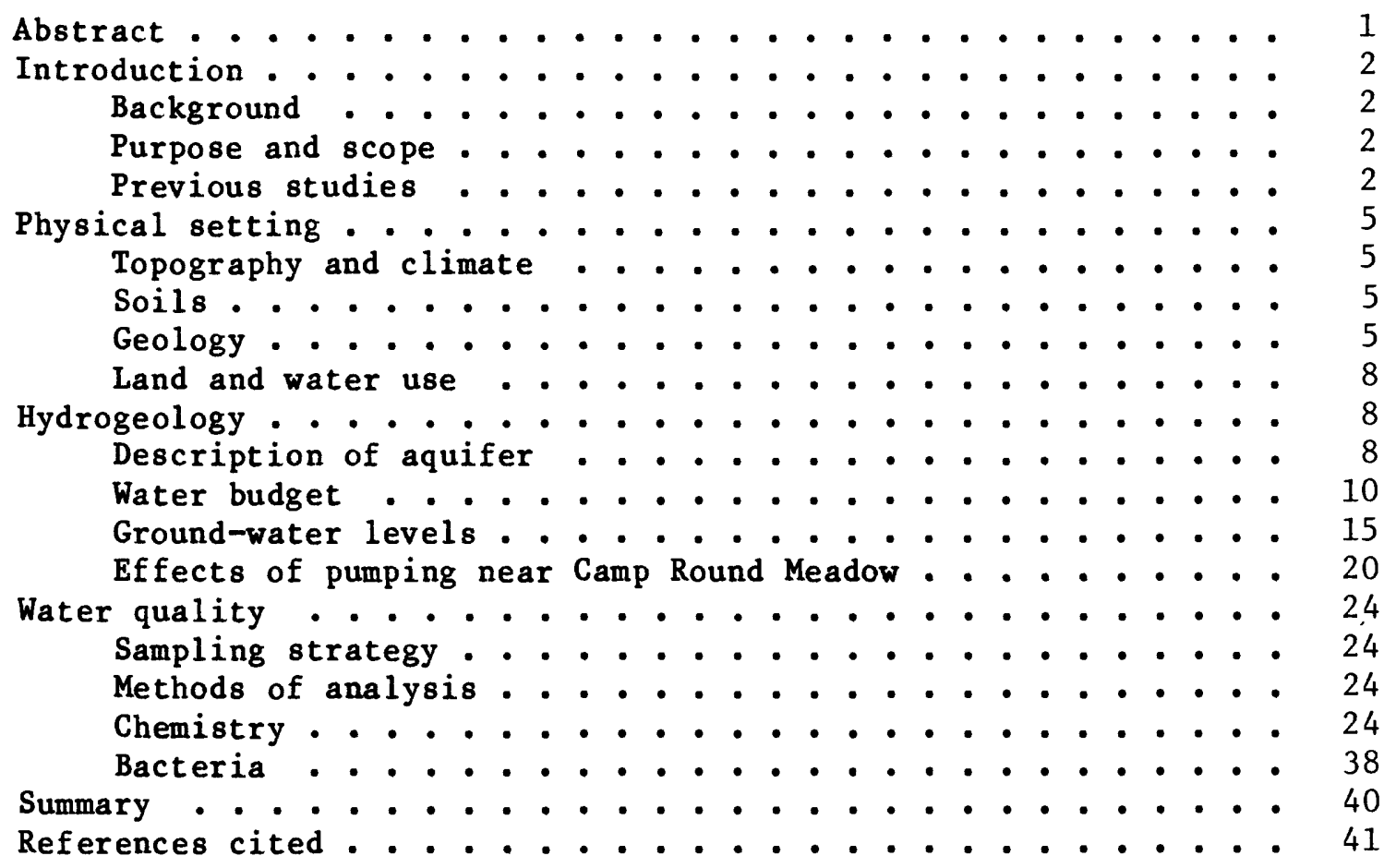

\section{ILLUSTRATIONS}

Figure 1. Map showing location of study area . . . . . . . 3

2. Map showing location of sampling sites . . . . . 4

3. Map showing topography of the Catoctin Mountain National Park area . . . . . . . 6

4. Map showing geology of the Catoctin Mountain National Park area ........... 7

5. Map showing salted roads and Camp Round Meadow septic lagoon and sand filters ........ 9

6. Graph showing yield, caliper, and lithologic logs for well BD 111 .............. 11

7. Map and hydrogeologic section of Camp Round Meadow. - 12 
Figure 8. Schematic diagram of the hydrologic cycle .....

9. Graph showing estimated monthly water budgets for the Catoctin Mountain National Park area . . . . .

10. Graph showing daily high water level in well BD 111 , November 22, 1983, through December $31,1984 \ldots$.

11. Graph showing water levels in wel1 BD 114 during aquifer test on November 30,1983 . . . . . .

12. Graph showing water levels at Camp Round Meadow wells during aquifer test of well BD 35 , November 29,1983 . . . . . . . . . .

13. Graph showing water level in well BD 111 , November $22-28,1983$. . . . . . . . .

14. Graph showing water levels at Camp Round Meadow observation wells during aquifer test, April 16-17, 1984 ...............

15. Graph showing relationship of calcium concentration to alkalinity for all sites sampled ........

16. Graph showing relationship of chloride concentration to nitrite plus nitrate concentration for all sites sampled, and corresponding water types ...

17. Map showing generalized classification of sampling sites in terms of the six chloride and nitrite plus nitrate water types ..............

TABLES

Page

Table 1. Characteristics of selected wells in the Catoctin Mountain National Park area..........

2. Water-quality data for the Catoctin Mountain National

Park area, for the period 1983-84. . . . . . 26

3. Results of fecal streptococcus confirmation tests . . 39 


\section{CONVERSION FACTORS AND ABBREVIATIONS}

For the convenience of readers who may prefer to use metric (International System) units rather than the inch-pound units used in this report, values may be converted by using the following factors:

\begin{tabular}{|c|c|c|}
\hline Multiply Inch-Pound Unit & By & To Obtain Metric Unit \\
\hline inch (in.) & 25.4 & millimeter (mm) \\
\hline foot $(f t)$ & 0.3048 & meter (m) \\
\hline gallon (gal) & 3.7850 & liter (L) \\
\hline $\begin{array}{l}\text { gallon per minute } \\
\text { (ga1/min) }\end{array}$ & 0.0631 & $\begin{array}{l}\text { liter per second } \\
(\mathrm{L} / \mathrm{s})\end{array}$ \\
\hline $\begin{array}{l}\text { gallon per minute per foot } \\
{[(\mathrm{gal} / \mathrm{min}) / \mathrm{ft}]}\end{array}$ & 0.2070 & $\begin{array}{l}\text { liter per second per meter } \\
{[(\mathrm{L} / \mathrm{s}) / \mathrm{m}]}\end{array}$ \\
\hline
\end{tabular}




\title{
HYDROGEOLOGY AND WATER QUALITY OF THE \\ CATOCTIN MOUNTAIN NATIONAL PARK AREA, FREDERICK COUNTY, MARYLAND
}

By Thomas J. Trombley and Linda D. Zynjuk

\begin{abstract}
The Catoctin Mountain National Park area, located in the Blue Ridge physiographic province of central Maryland, is characterized by high local relief, an average annual precipitation of 44 inches, and stony soils underlain by weathered and fractured metamorphic rocks. The park is mostly forested land and includes several camps and roads. The ground-water reservoir consists of regolith and underlying fractured bedrock and is recharged by precipitation. Discharge from the ground-water flow system is mainly to nearby streams adjacent to areas of recharge. Approximately 56 percent of annual streamflow is contributed by ground water.

Wells located at Camp Round Meadow and Staff Quarters No. 5 can sustain pumping rates of 45 to 60 gallons per minute for several hours, with drawdowns of 40 to 50 feet. Water-quality samples from wells, springs, and streams indicate that ground water is slightly affected by septic waste and road salt. Ground water in remote areas is not affected by either source. Concentrations of chloride from road salt and concentrations of nitrate plus nitrite (as $N$ ) were below U.S. Environmental Protection Agency drinkingwater limits in all ground- and surface-water samples.
\end{abstract}




\section{INTRODUCT ION}

\section{Background}

Catoctin Mountain National Park is located in Frederick County, Md., in the Blue Ridge physiographic province of central Maryland (fig. 1). Park facilities have expanded and park usage has increased since the mid-1960's. These changes have placed increased stress on the ground-water resources. The park's water supply is derived from wells, and the park's streams, which derive much of their flow from ground water discharged through springs and seeps, are a major spawning area for trout. It is important to determine the effects of park development on water quality and quantity within the hydrogeologic framework of the park. Therefore, in 1983, the U.S. Geological Survey, in cooperation with the National Park Service, began a study to evaluate the hydrogeology and water quality of the park area.

\section{Purpose and Scope}

The purpose of this report is to describe the hydrogeology and water quality of the Catoctin Mountain National Park area. The study was accomplished in two phases. The first, which lasted for 6 months, was a reconnaissance of the area to characterize the ground-water flow system and to make a preliminary assessment of ground-water quality. Water levels were measured in wells throughout the park (fig. 2). Also, water samples were collected from 15 wells, 13 springs, and 7 stream sites throughout the park and analyzed for major chemical constituents.

The second phase, which lasted for 15 months, was to compile more complete information at selected sites throughout the park. Three observation wells were drilled at Camp Round Meadow and one was drilled at Staff Quarters No. 5. Aquifer tests were conducted on one production well at Camp Round Meadow and on the observation well at Staff Quarters No. 5. Water samples were collected quarterly from seven wells and five springs for chemical and bacterial analysis.

\section{Previous Studies}

The Ecological Services Laboratory of the National Park Service conducted a 3-year study from October 1978 through November 1981; the approach entailed the collection of monthly water-quality data at eight stream sites, five wells, two springs, and two sewage lagoons located in Camp Round Meadow. Results of this study indicated a healthy stream and well system (R.S. Hammerschlag, National Park Service, written commun., 1983), but suggested more detailed study of the ground-water system. Huth Engineers and R.E. Wright Associates (1981) conducted a study to evaluate the adequacy of the water supply, waste-water disposal, and fire protection systems in the park. The results of their study indicated possible low-level septic contamination of the Camp Round Meadow wells, but concluded that the overall water quality was well within national drinking-water standards as determined by the U.S. Environmental Protection Agency (1976). 


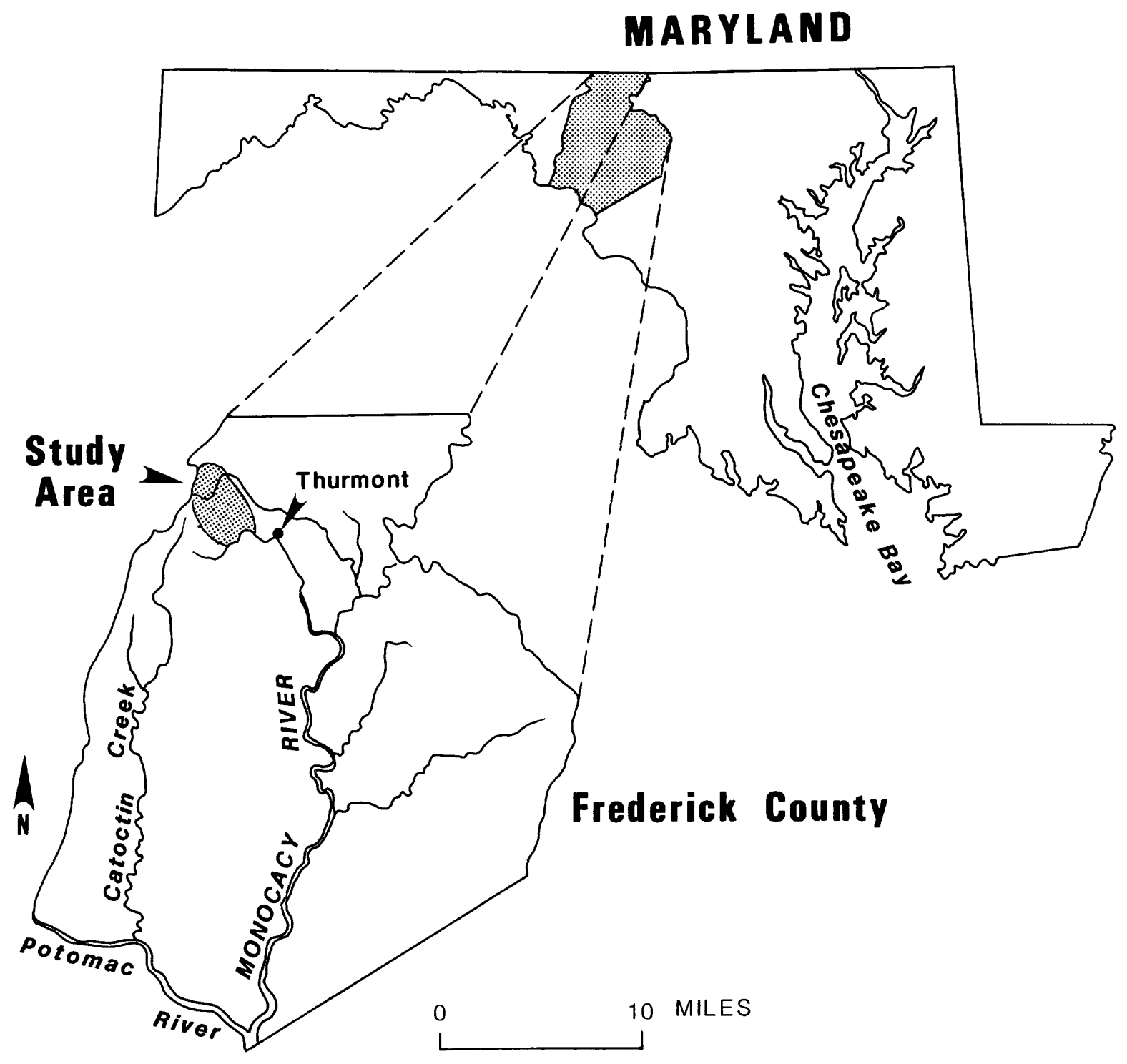

Figure 1. Location of study area. 

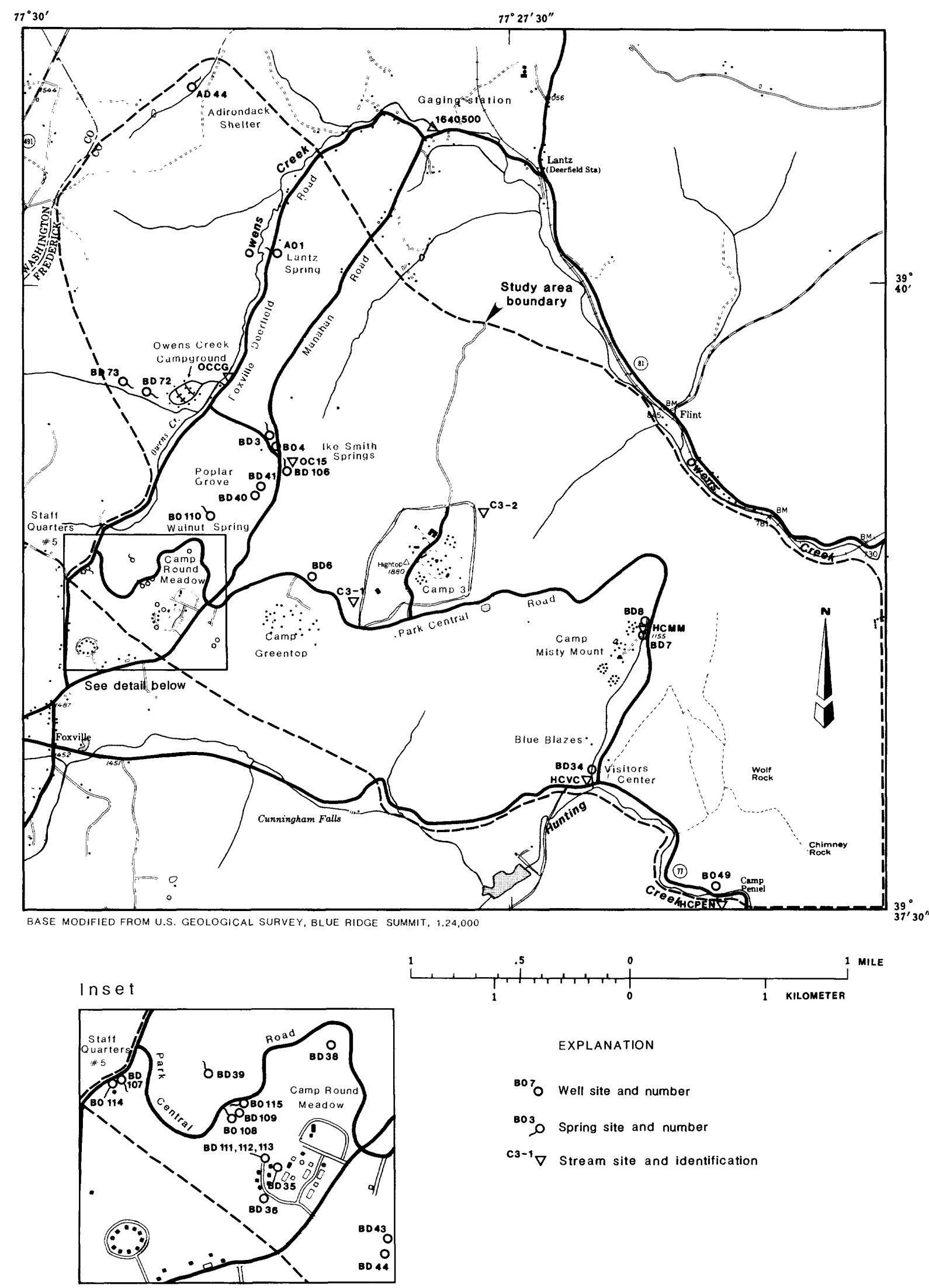

EXPLANATION

${ }^{807} \mathrm{O}$ Well site and number

${ }^{\text {B03 }} \mathrm{O}$ Spring site and number

${ }^{c 3^{-1}} \nabla$ Stream site and identification

Figure 2. Location of sampling sites. 
PHYSICAL SETTING

\section{Topography and Climate}

Catoctin Mountain is a discontinuous ridge that extends from near the Pennsylvania-Maryland border to the Potomac River at Point of Rocks, Maryland (Vokes and Edwards, 1957 , p. 69). The park area is separated from the main ridge by two streams--in the south by Hunting Creek, and in the west, north, and east by Owens Creek (fig. 3 ). The terrain is rugged and there is a maximum of approximately $1,080 \mathrm{ft}$ of relief between Camp Peniel (800-ft elevation) and Camp 3(1,880-ft elevation). Slopes in the park area generally are between 10 and 20 percent, but may be as high as 60 percent.

Precipitation in the area is approximately $44 \mathrm{in} / \mathrm{yr}$ (U.S. Department of Commerce, 1968). Monthly distribution of the precipitation is fairly even throughout the year with a low of 2.66 in. in February and a high of 4.75 in. in August. Precipitation exceeds 0.01 in. for about 130 days in the average year. Snowfall averages approximately $24 \mathrm{in} / \mathrm{yr}$.

\section{$\underline{\text { Soils }}$}

Soils in the park are characterized in the Soil Survey of Frederick County (Matthews, 1960, map sheets 5,6,9,10) as primarily rough stony land. They are well drained, poorly developed soils containing numerous stones and boulders throughout the profile. In draws and valleys, such as near Camp Greentop and Camp Round Meadow, the soils belong to the Highfield series, which is characterized by well-drained, fairly deep, stony loams containing many stones and some boulders.

\section{$\underline{\text { Geology }}$}

Three rock formations of late Precambrian age (Fauth, 1977) are exposed in Catoctin Mountain National Park (fig. 4). The oldest rocks in the park belong to the Catoctin Formation. Two main rock types are included in the Catoctin Formation in the park--a greenish to greenish-gray and gray metabasalt, which underlies most of the area, and a bluish to grayish metarhyolite in which most of the wells and springs are sited. A small area of porphoritic metabasalt is located south of the study area in Cunningham Falls State Park. The Loudon Formation, also on the southeastern side of the park, has two lithologic subdivisions--a lower member, consisting of a phyllite, and an upper member, consisting of a conglomerate. The Weaverton Formation lies along the southeastern edge of the park and is divided into three members--a lower member, consisting of a graywacke with quartz-phy 1lite interbeds a middle member, consisting of a thick-bedded to massive, wel1-jointed, medium- to coarse-grained quartzite; and an upper member, consisting of quartzite and conglomerate. Quaternary terraces are located outside the park area above the Owens Creek flood plain in Lantz, Md.; these consist of alluvial silt and clay deposits containing some sand layers. 

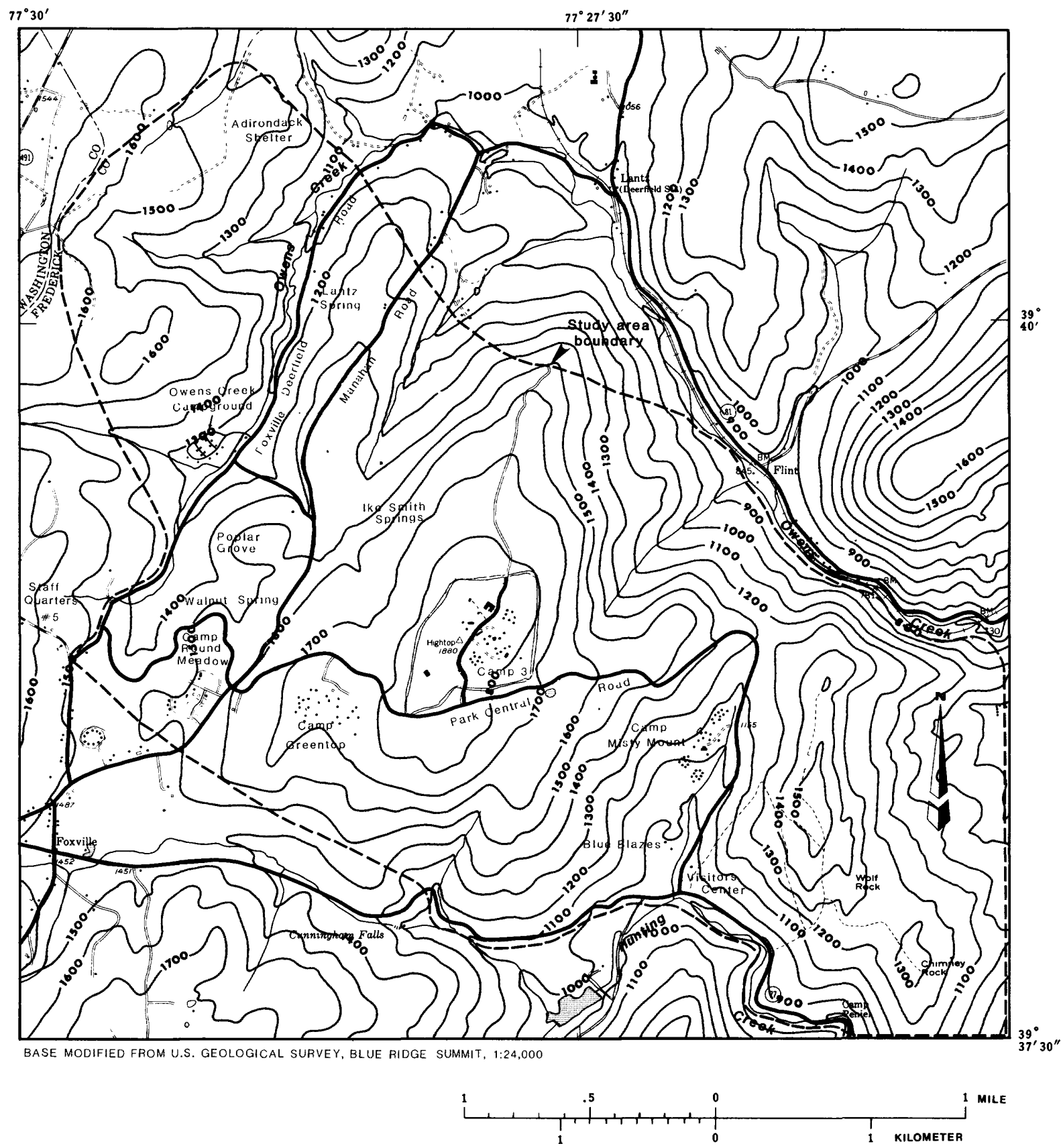

Contour interval 100 feet. Datum is sea level

Figure 3. Map showing topography of the Catoctin Mountain National Park area. 


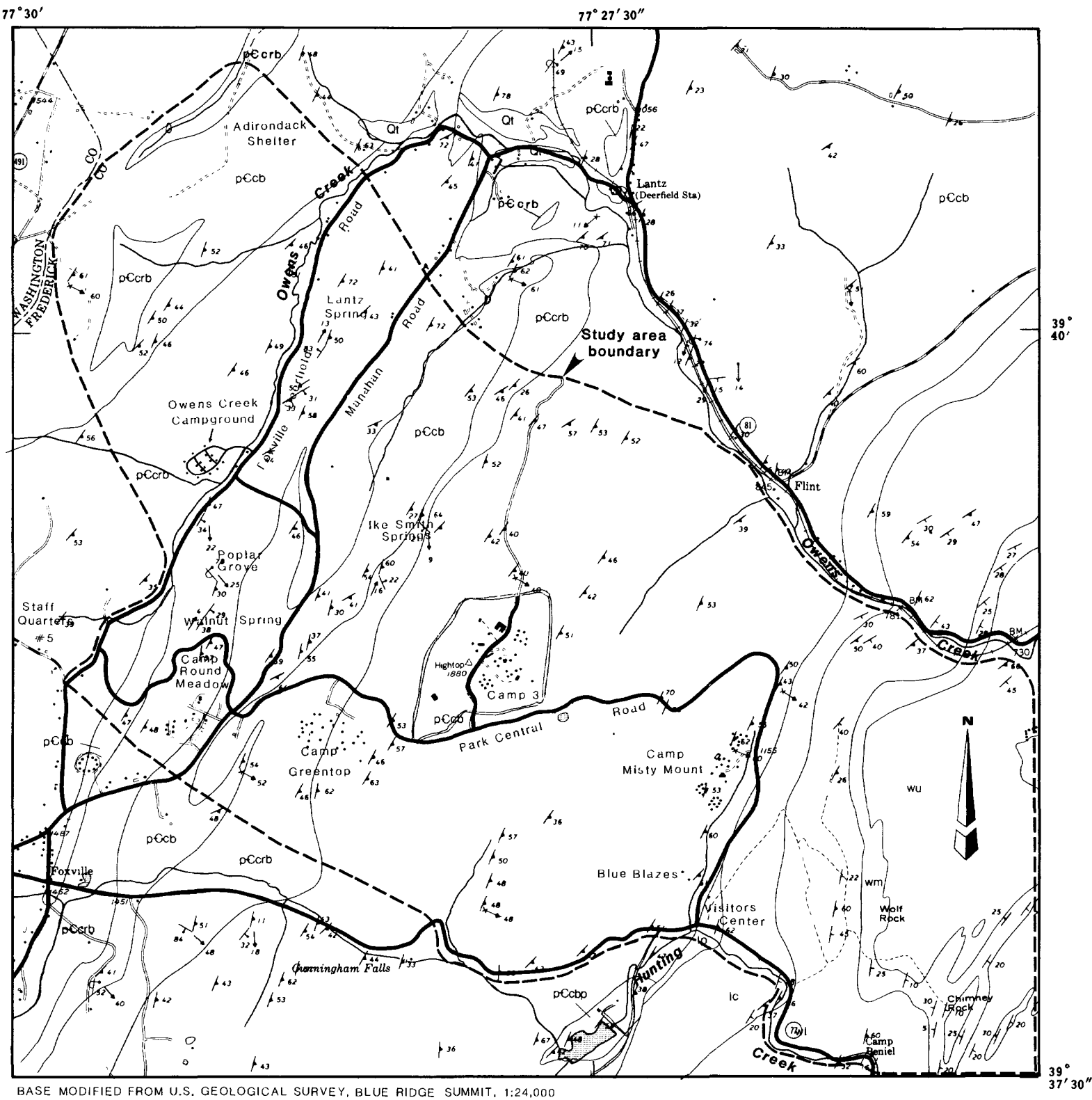

EXPLANATION

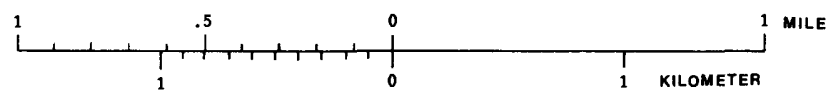

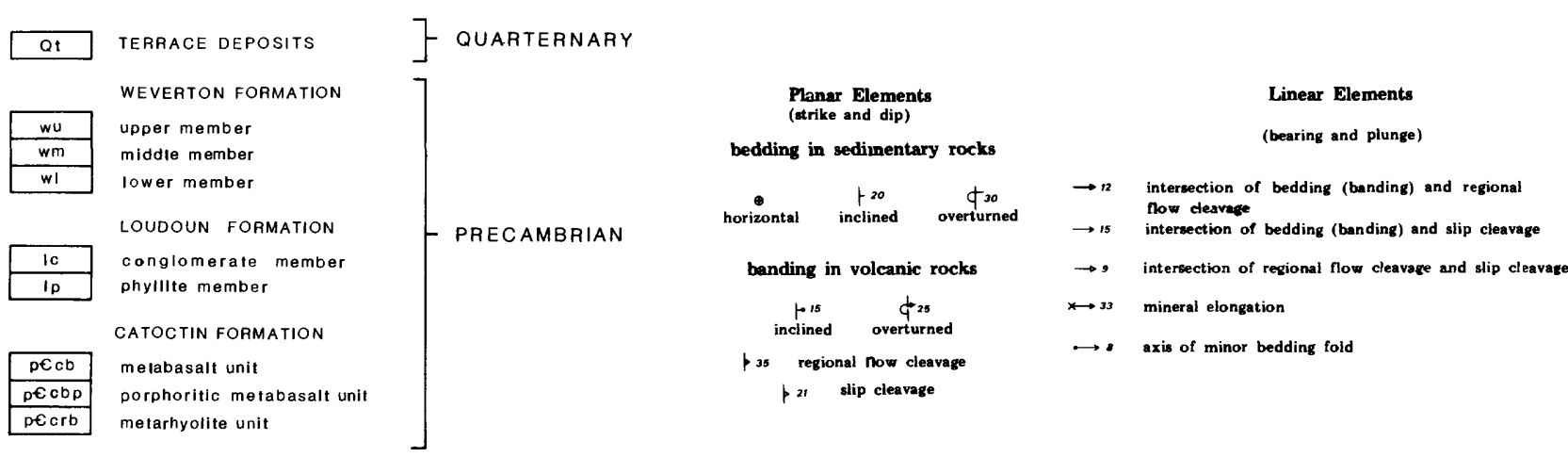

Figure 4. Map showing geology of the Catoctin Mountain National Park area. 
The rock units in the park area are highly fractured and folded. The axes of folding and major cleavage planes are northeast-southwest (Fauth, 1977). Cleavage planes and fractures dip approximately $45^{\circ} \mathrm{SE}$. In the Camp Round Meadow area, field observations of fracture patterns indicate two nearly vertical systems oriented approximately east-west and northwestsoutheast in addition to the tilted northeast-southwest system.

\section{Land and Water Use}

Prior to becoming a national park, Catoctin Mountain National Park was primarily forests and farmland. Stone walls, domestic springs, and building foundations can still be seen throughout the park. Today, it is mainly forested with several camps and picnic areas that are used by visitors throughout the year (fig. 2). Septic systems, originally installed in the $1930^{\prime} \mathrm{s}$, consist of a series of sand filters, septic tanks, and drain fields. Camp Round Meadow has a lagoon system (fig. 5) which treats raw sewage before it is pumped into two sand filters for final treatment. Camp 3 , which is occupied year round, has its own septic system. Other camps and picnic areas have concrete vaults that are pumped out periodically. Finally, the entire eastern side of the park has been connected to the municipal sewage system of nearby Thurmont, Md. Several of the roads in and near the park are salted during the winter (fig. 5); they are FoxvilleDeerfield Road, Route 77, Manahan Road near Camp Round Meadow, and Park Central Road from Foxville-Deerfield Road to Camp 3, and near the Visitors Center. Park Central Road from Camp 3 to just north of the Visitors Center is not salted.

\section{HYDROGEOLOGY}

\section{Description of Aquifer}

The framework for the ground-water flow system consists of bedrock overlain by regolith. The thickness of this regolith is related largely to topography; it is thinnest near the top of Catoctin Mountain and along ridges, and thickest in draws and valleys. The regolith consists of all the material above unaltered bedrock and includes transported and nontransported rock material. It is highly porous and permeable and, therefore, is the principal ground-water reservoir. Where the regolith is saturated, ground water occupies the spaces between unconsolidated rock particles. In the unaltered bedrock, however, ground water is present in secondary openings along bedding planes, cleavage planes, joints, and faults. Commonly, these openings were enlarged by weathering from ground water. The number and size of the openings determines the porosity, and the degree to which the openings are interconnected determines the permeability of the bedrock. The number, size, and interconnection of openings decrease with depth below land surface due to the increase in pressure and the decrease in weathering. Porosity and permeability also are related to topographic setting because openings are fewer beneath ridges and more abundant beneath draws and valleys. 


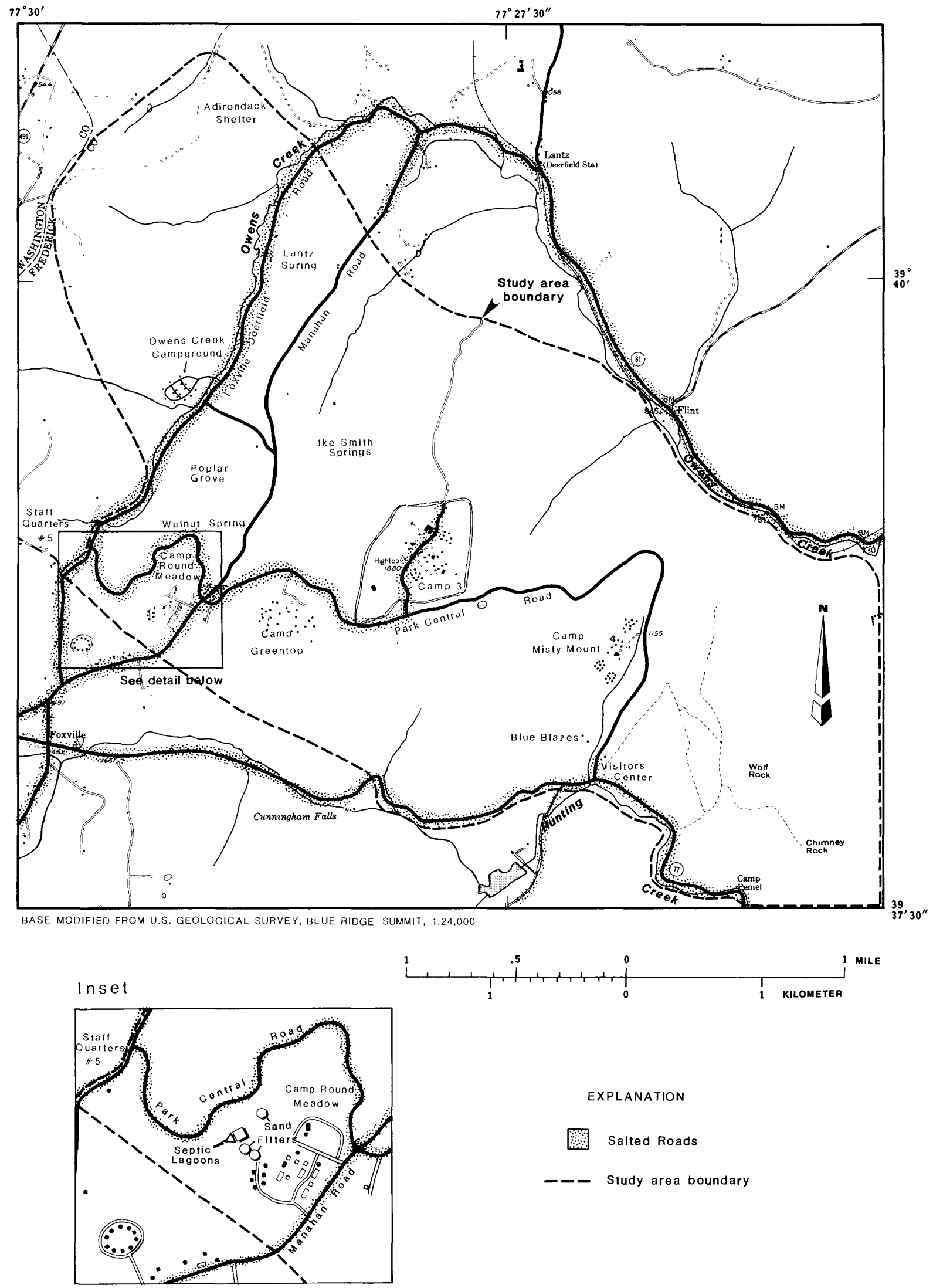

Figure 5. Salted roads and Camp Round Meadow septic lagoon and sand filters 
Ground water in the regolith is under unconfined conditions. In contrast, ground water in the secondary openings in unaltered bedrock commonly is under confined conditions because the bedrock that borders the openings is virtually impermeable. However, because there are no well-defined, continuous confining beds in the regolith, and because the degree of hydraulic connection between the regolith and the secondary openings in the bedrock is generally high, the entire ground-water flow system can be considered as one, complex, unconfined aquifer.

The water table generally is a subdued replica of the land surface. It is deepest under ridges and nearest land surface in draws and valleys. It is commonly in the regolith, but the water table can also be in the bedrock, especially under ridges.

The regolith extends to a depth of approximately $200 \mathrm{ft}$ in a well at Camp Round Meadow (fig. 6). At Staff Quarters No. 5, it is approximately 45 ft thick, and open fractures in bedrock extend to a depth of approximately $95 \mathrm{ft}$. The hydrogeologic section shows the estimated thickness of the regolith and the depth to unweathered bedrock as well as an approximation of the water table under normal pumping conditions. The information on the section is derived from logs of the observation wells at Camp Round Meadow and from aquifer tests on November 29, 1983, and April 17, 1984. Figure 7 is a conceptualization of the ground-water system in the vicinity of Camp Round Meadow.

\section{Water Budget}

A water budget is an accounting system for the water entering and leaving a drainage basin (fig. 8). It is defined by:

$$
P-S R-B F-G U-E T+\Delta S=0
$$

where

$$
\begin{aligned}
\mathrm{P}= & \text { precipitation } \\
\mathrm{SR}= & \text { surface-runoff component of streamflow; } \\
\mathrm{BF}= & \text { ground-water base-flow component of streamflow; } \\
\mathrm{GU}= & \text { ground-water underflow; } \\
\mathrm{ET}= & \text { evapotranspiration; and } \\
\Delta \mathrm{S}= & \text { changes in storage (includes changes in ground-water } \\
& \text { levels, accumulation and melting of snow, and } \\
& \text { freezing/thawing of soil moisture). }
\end{aligned}
$$




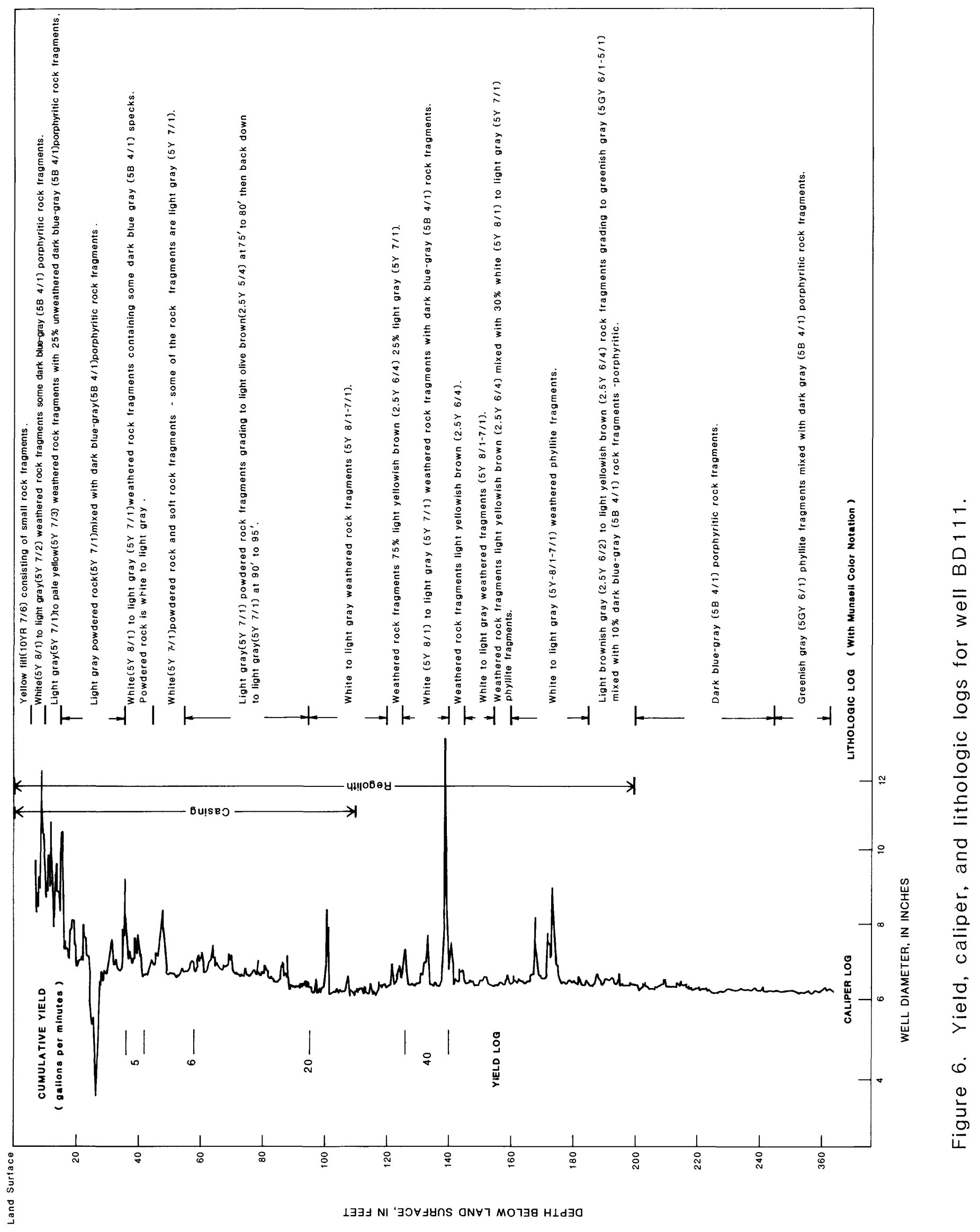




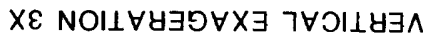

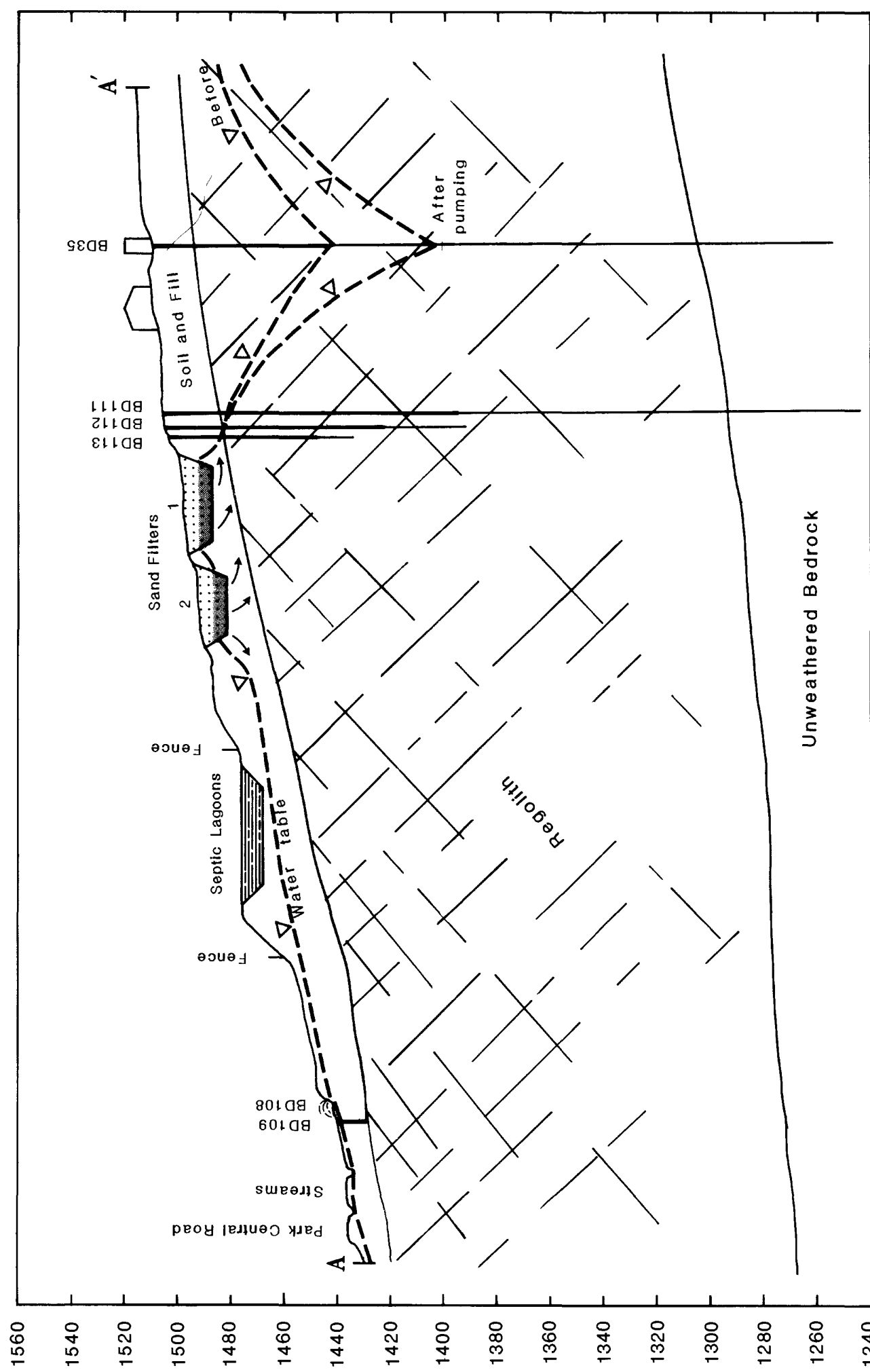

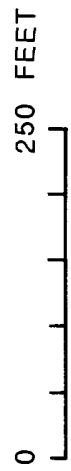

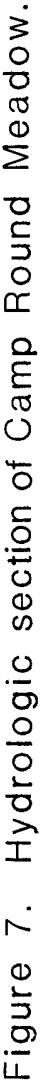

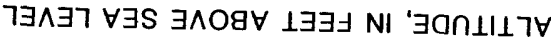




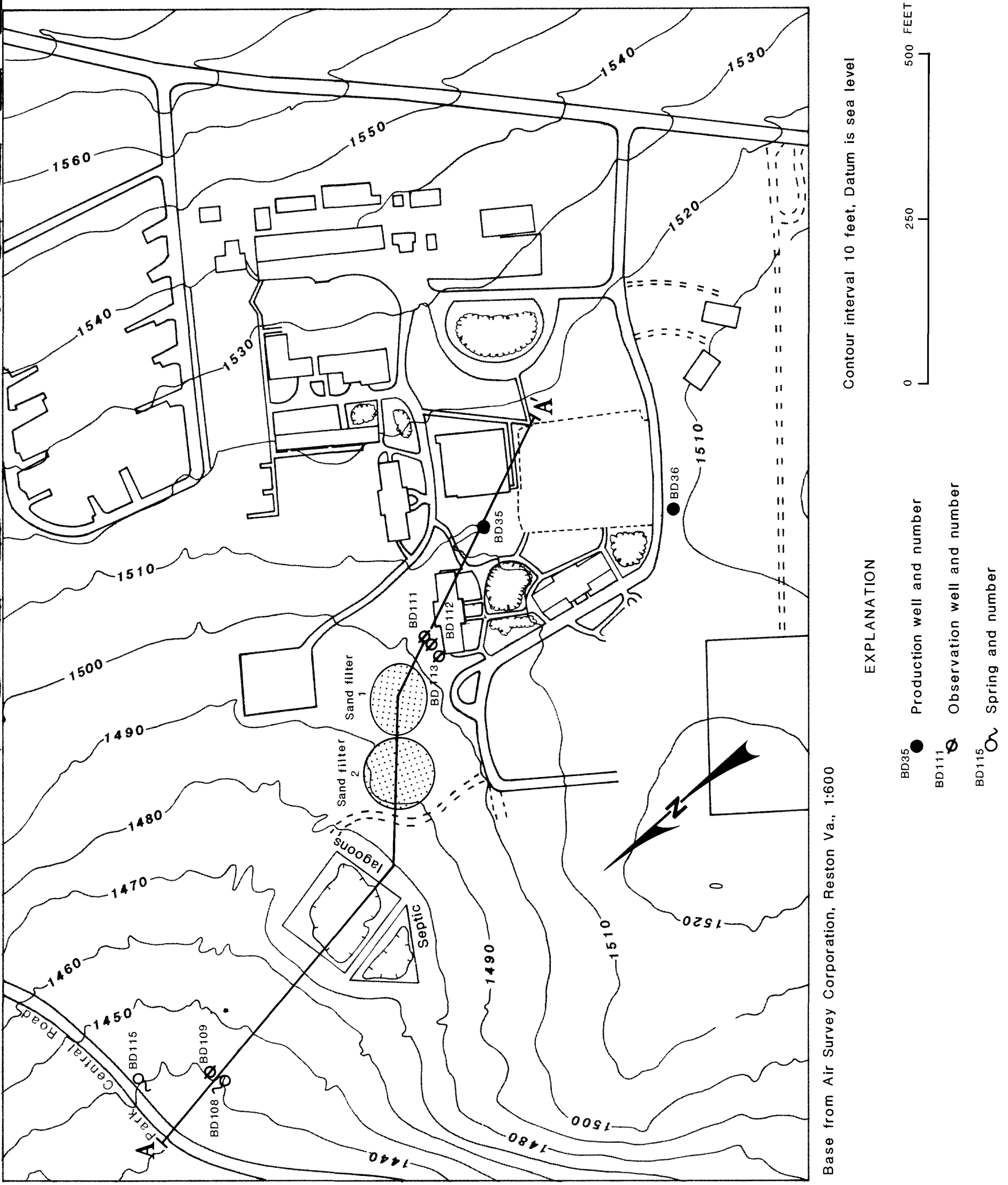

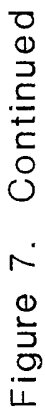




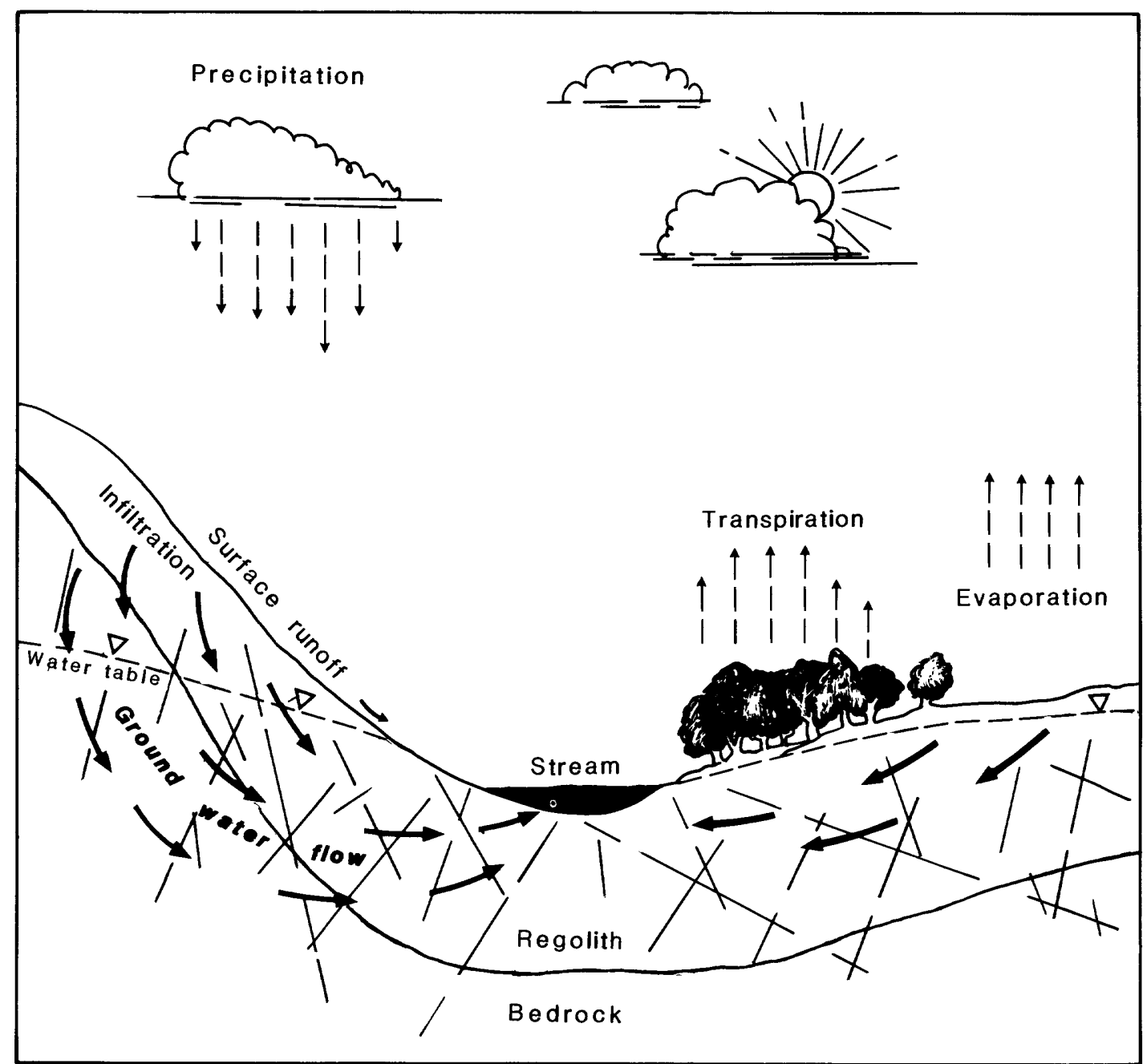

Figure 8. Schematic diagram of the hydrologic cycle. 
Figure 9 is an estimate of monthly water budgets for Catoctin Mountain National Park from October 1, 1983, through September 30, 1984. Pumpage from wells is a minor constituent which is not considered here because most of the water is eventually returned through septic systems. Precipitation was determined from rain-gage data supplied by National Park Service personnel at Catoctin Mountain National Park. Surface runoff and ground-water base flow were separated from total streamflow in Owens Creek measured at the U.S. Geological Survey stream-gage station in Lantz, Maryland (adjacent to Catoctin Mountain National Park), using a graphical method described by Linsley and others (1958, p. 156).

Ground-water underflow, evapotranspiration, and changes in storage were not evaluated separately. The sum of these three terms is expressed as the difference between precipitation and observed streamflow. During months when streamflow exceeded precipitation, the excess (January, February, and April) may be due largely to runoff caused by melting snow. During months when streamflow was much less than precipitation (October, July, and August), evapotranspiration probably accounted for most of the difference.

Steady-state conditions were assumed for estimating the annual budget. This allowed the change-in-storage term to be ignored. The assumption was made because water levels in well BD 111 were approximately equal at the beginning and end of the year. Surface runoff accounted for 25 percent ( $16.8 \mathrm{in.)}$ of the annual precipitation ( $67.5 \mathrm{in.})$, ground-water base flow accounted for 32 percent $(21.7$ in.), leaving 43 percent ( 29 in.) for evapotranspiration. Based on these figures, approximately 56 percent of total streamflow was contributed by ground water.

\section{Ground-Water Levels}

Table 1 lists characteristics of wells throughout the park. Water levels measured in these wells during the study period ranged from flowing, at BD 7, to about $69 \mathrm{ft}$ below land surface at BD 40 . Seasonal fluctuations of water level for well BD 111 are shown in figure 10. The highest water levels were in mid-February through April when much precipitation entered the ground-water system ( $f i g .9$ ), and the lowest water levels occurred in late summer when only a small percentage of precipitation recharged the ground-water system because of high evapotranspiration rates (fig. 9). Declines in water level are primarily because of ground-water discharge to streams.

In addition to water-level fluctuations caused by seasonal climatic conditions, water levels also fluctuate due to pumping. On November 30 , 1983, a new well (BD 114) at Staff Quarters No. 5 was pumped for 5 hours. Figure 11 is a plot of the drawdown and recovery resulting from the test. Two inserts in the figure are semi-log plots. The top inset shows both drawdown and recovery plotted as functions of time since pumping started. The bottom inset is recovery plotted against time since pumping stopped. The figure shows a boundary effect where the water level is drawn down rapidly and then starts to level off. As the boundary is reached, the water level begins to decline rapidly again. This boundary effect is seen in both the semi-log plots of drawdown and recovery as a change in slope, and may indicate a change in local hydraulic properties of the rock. 


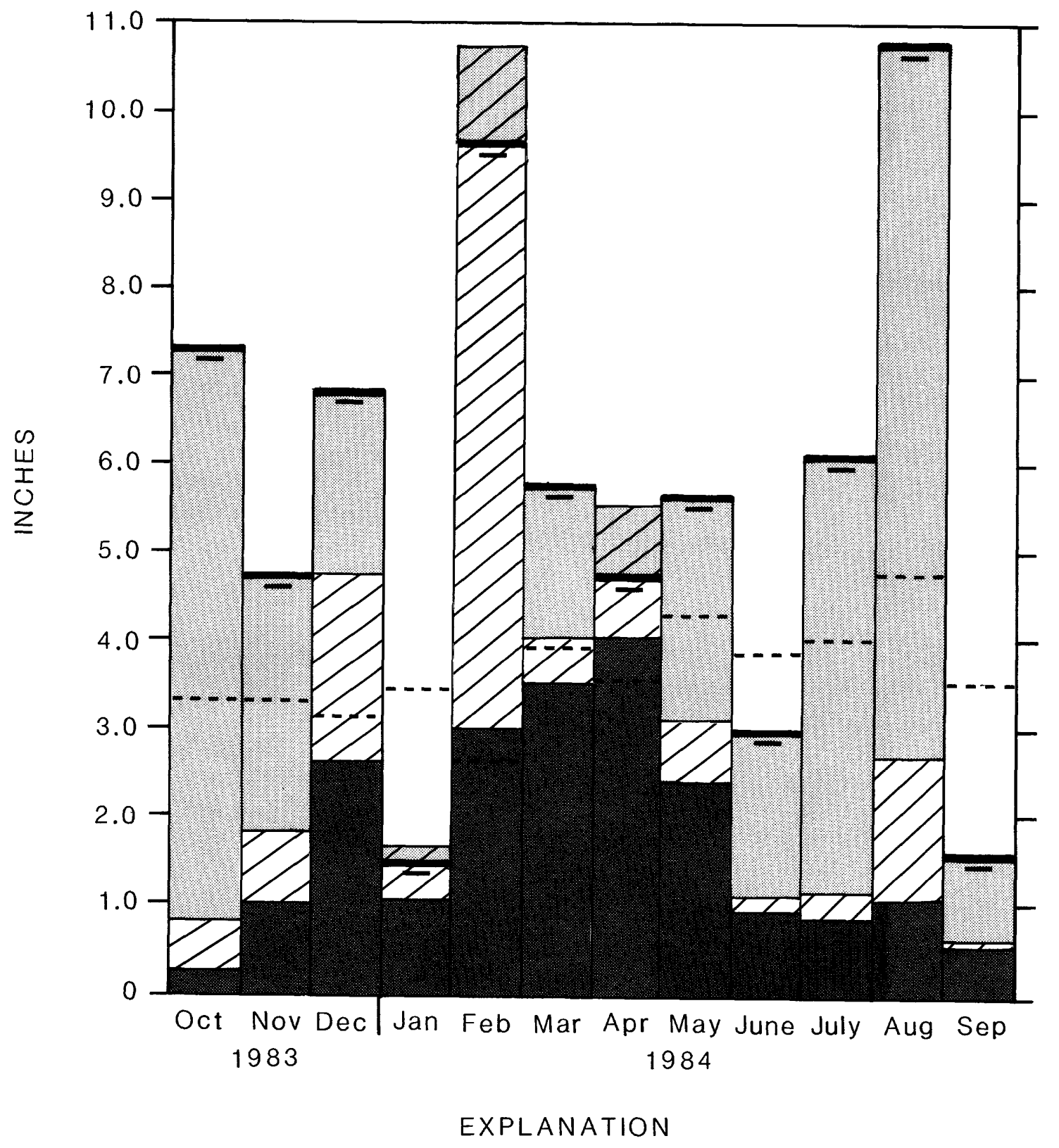

Evapotranspiration, changes in ground-water storage, ground-water underflow, and ice and snow.

Surface runoff

Ground-water base flow

Total monthly precipitation measured at Catoctin Mountain National Park

Mean annual precipitation for North Central Maryland
(1931-1955) (U.S. Department of Commerce, 1968)

Figure 9. Estimated monthly water budgets for the Catoctin Mountain National Park area. 


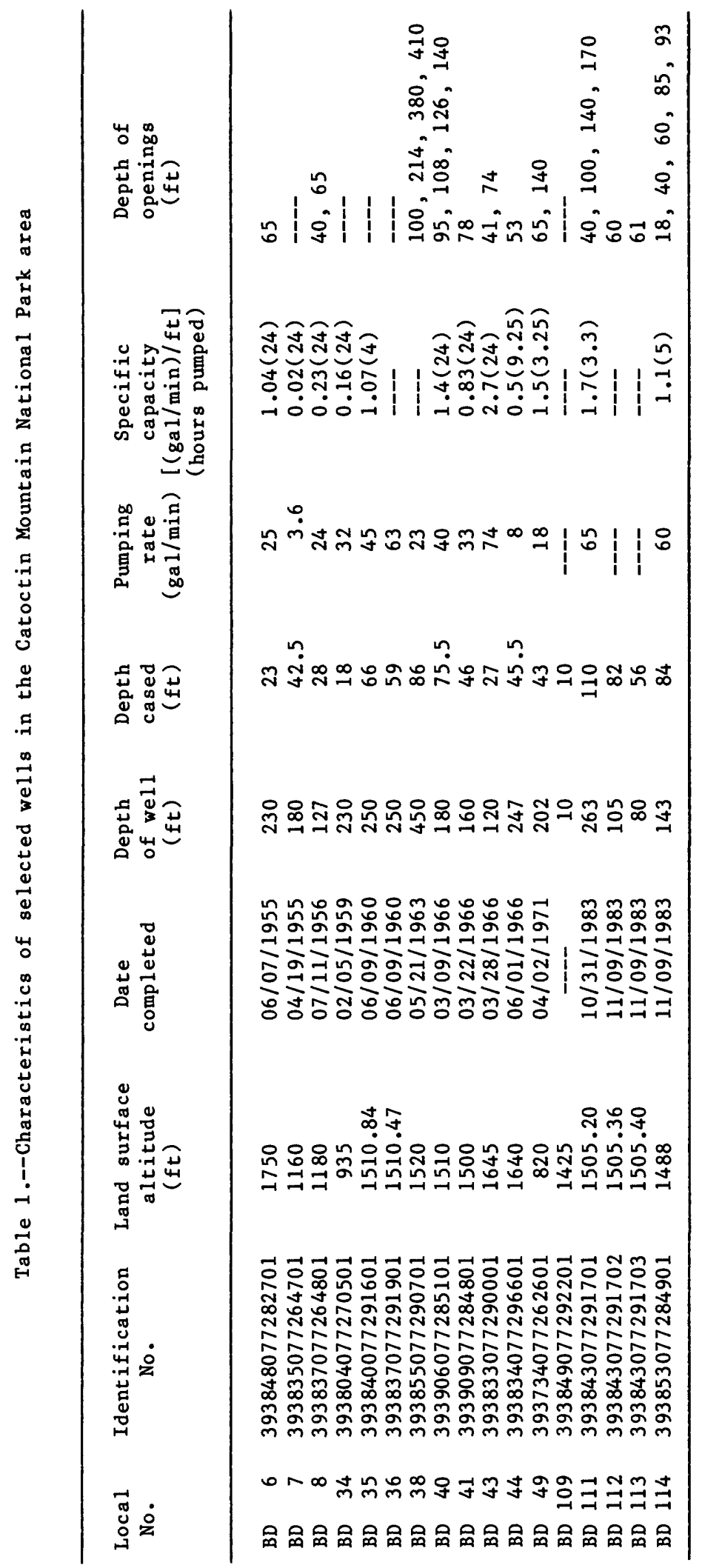




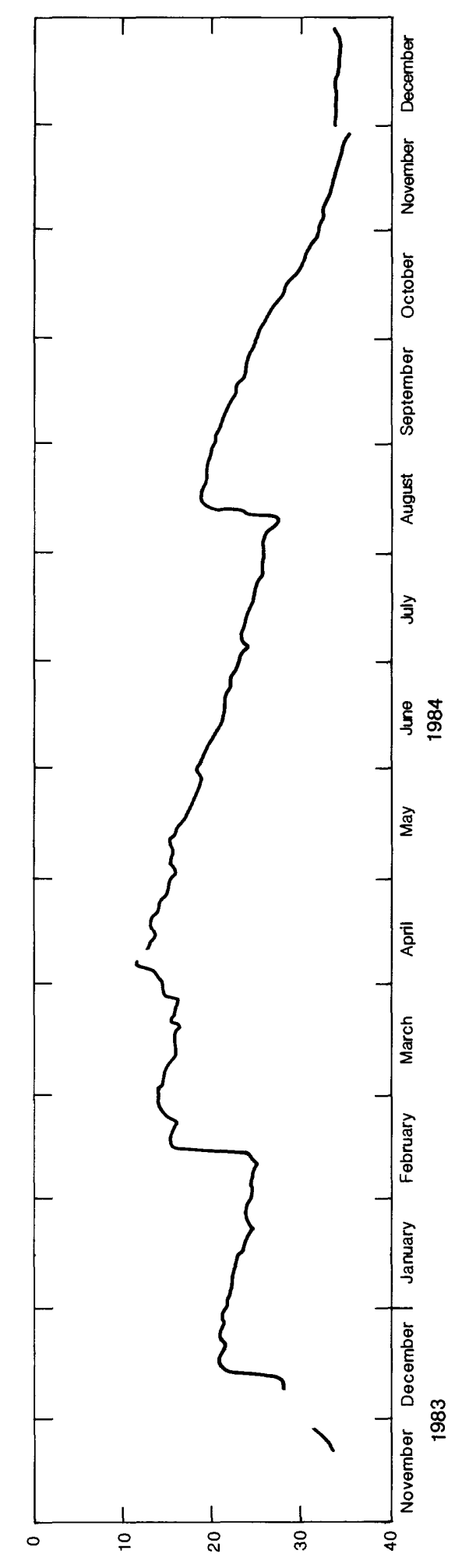

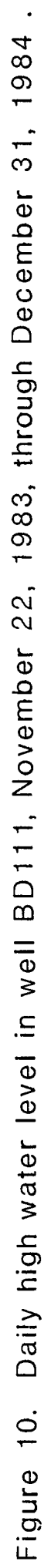

$\exists 0 \forall\lrcorner 4$ ก व 


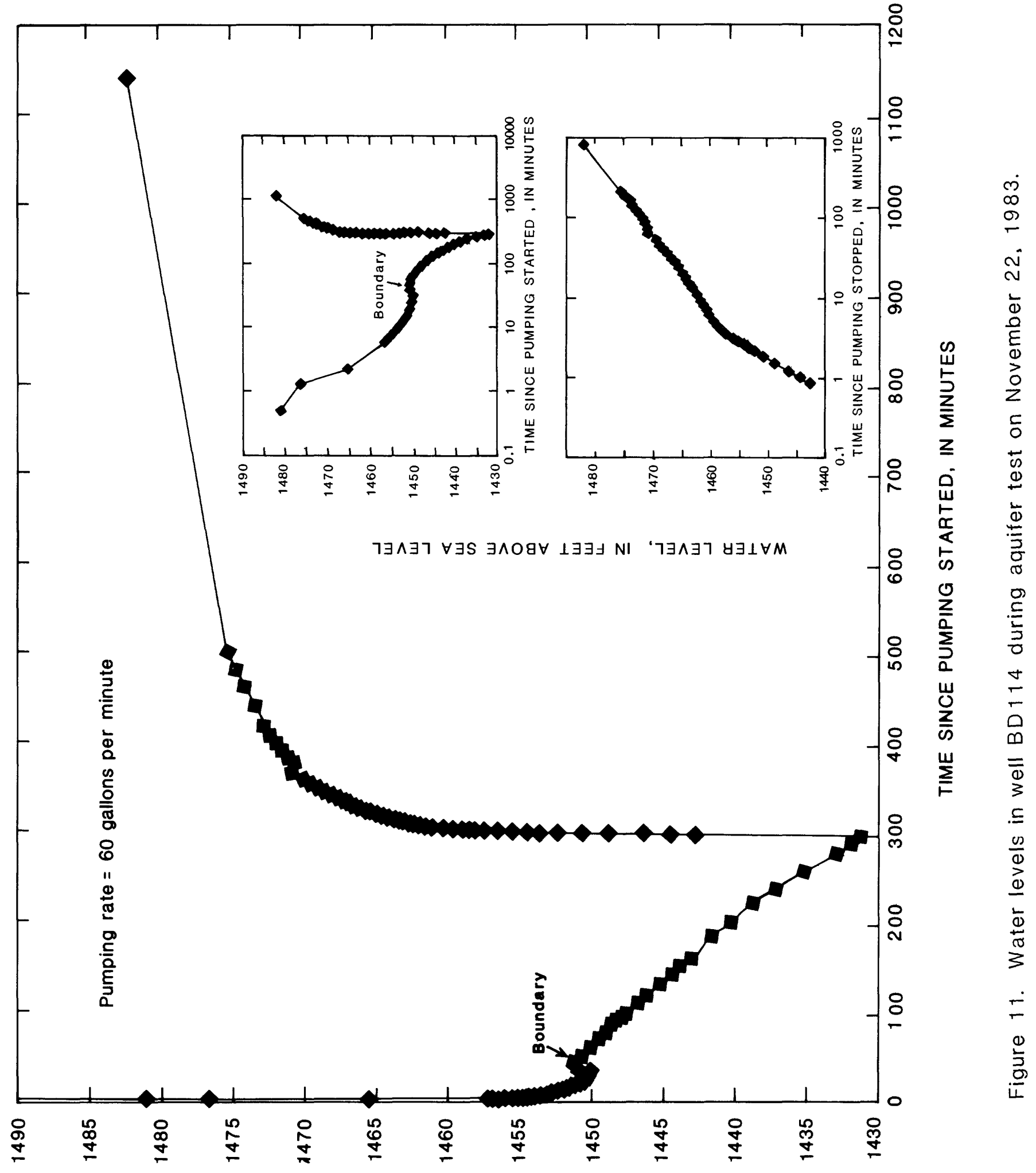

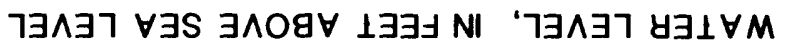




\section{Effects of Pumping near Camp Round Meadow}

Camp Round Meadow, located on the western side of the park (fig. 7), is an area of particular concern because two production wells are located near sewage treatment facilities. Sewage from the camp and from a nearby trailer park is treated in a two-stage aerated lagoon, pumped into one of two subsurface sand filters for final treatment, and then infiltrates to the ground-water system (see fig. $7 \mathrm{a}$ ). Well BD 35 , one of these production wells, is $270 \mathrm{ft}$ from the center of the nearest sand filter and $125 \mathrm{ft}$ from the nearest sewerline. The other production wel1, BD 36 , is $450 \mathrm{ft}$ from the nearest sand filter a sewerline is within a few feet of the wellhouse. Three observation wells (BD 111 to 113) were drilled in a cluster approximately $70 \mathrm{ft}$ from the center of sand filter no. 1 , located $200 \mathrm{ft}$ from BD 35 and $400 \mathrm{ft}$ from BD 36. Wel1 BD 111 is $263 \mathrm{ft}$ deep; well BD 112 is $105 \mathrm{ft}$ deep; and well BD 113 is $80 \mathrm{ft}$ deep. A 1,000-gallon-capacity pump pit and a 1,500-gallon-capacity solids tank used for septic waste from two locations are located $150 \mathrm{ft}$ from BD 36 .

An aquifer test was conducted at well BD 35 on November 29,1983 . The well was pumped at $45 \mathrm{gal} / \mathrm{min}$ for 240 minutes. An analysis of the data suggests that filtered sewage may be moving toward this production well. Figure 12 is a graph of the water levels measured at the pumping well and at the three observation wells. Although the observation wells are only $10 \mathrm{ft}$ apart, they did not have similar water levels. The deepest well (BD 111) had the lowest water level, and the shallowest well (BD 113) had the highest water level. Thus, there was a slight downward flow gradient, suggesting that shallow ground water may have been flowing downward as well as laterally. There was no apparent drawdown in these observation wells during the test due to rising water levels (fig. 13) resulting from 1.07 in. of rain on November 24 and 25 , and 0.63 in. of rain that fell between 4:00 a.m. on November 28 and 3:00 a.m. on November 29 .

Water levels in all three observation wells were higher than in the pumped well, indicating that ground water was flowing toward BD 35 from the northwest where the sand filters are located to the southeast (fig. 7); the set of fractures and cleavage that dip to the southeast is a potential pathway for water after percolating through the sand filters.

When the production wel1s (BD 35, BD 36) located at Camp Round Meadow are being pumped, the water level in BD 111 drops approximately $0.5 \mathrm{ft}$ ( $\mathrm{fig}$. 13). To determine how much of this drawdown is caused by each production well and what the effect is on the other two observation wells, an aquifer test was conducted at BD 111. After the two Camp Round Meadow production wells were idle for a day, well BD 36 was turned on and pumped at its normal rate beginning at $8: 30$ a.m., on April 17. BD 35 was turned on at 12:30 p.m. Both production wells were shut down at 4:50 p.m. Water levels in the observation wells were monitored during the test. The total drawdown in well BD 111 during the test was $0.57 \mathrm{ft}$ ( $\mathrm{fig}$. 14). Drawdown from pumping BD 36 was $0.14 \mathrm{ft}$ ( 25 percent). Therefore, assuming negligible well interference, drawdown from pumping BD 35 was $0.43 \mathrm{ft}$ ( 75 percent). The nearest production well (BD 35) had the greatest effect on water levels in BD 111 , which is drilled to approximately the same depth as BD 35 . The effects on BD 112 and BD 113 were less because they are not as deep as BD 111 and do not tap the same fractures. 


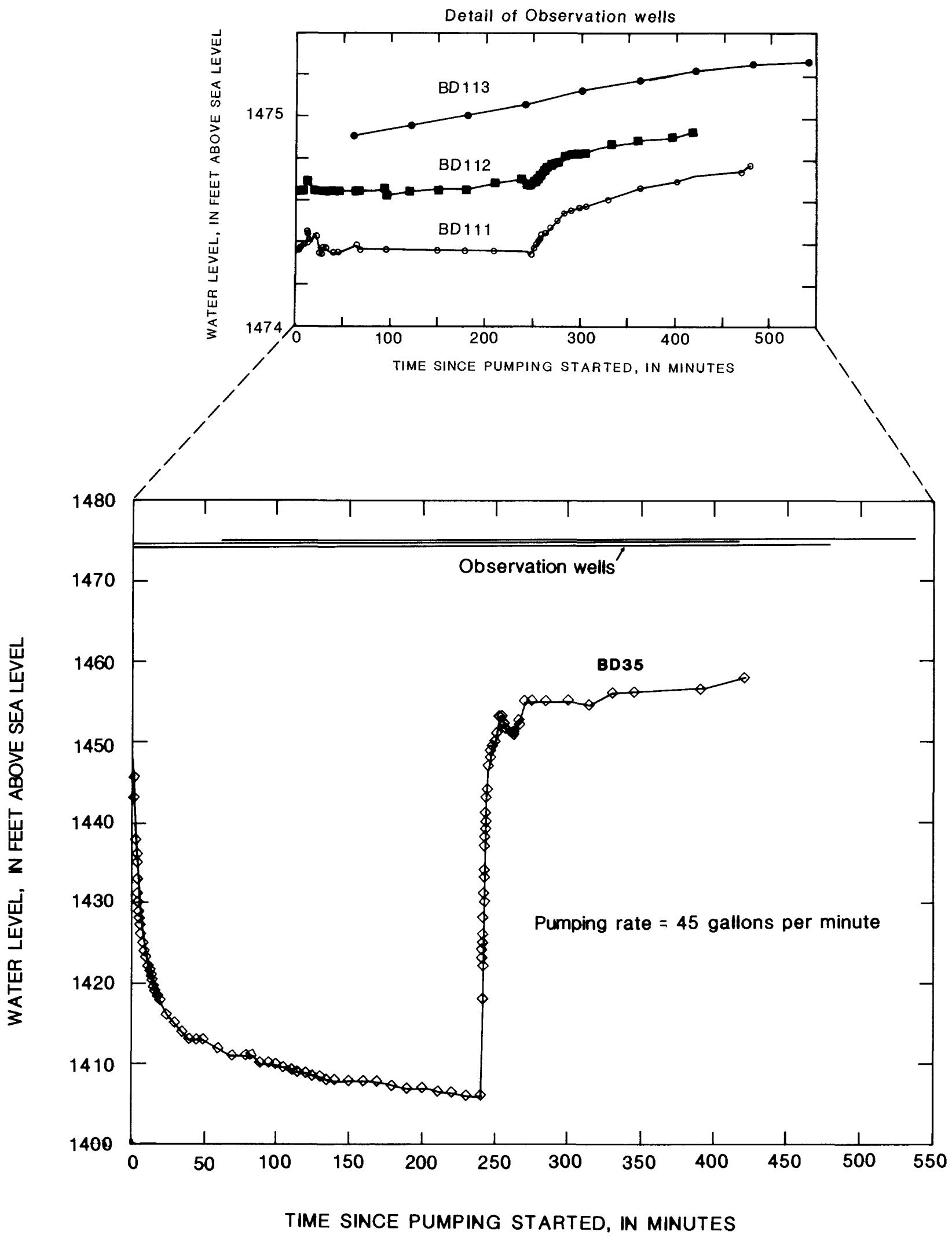

Figure 12. Water levels at Camp Round Meadow wells during aquifer test of well BD35, November 29, 1983. 


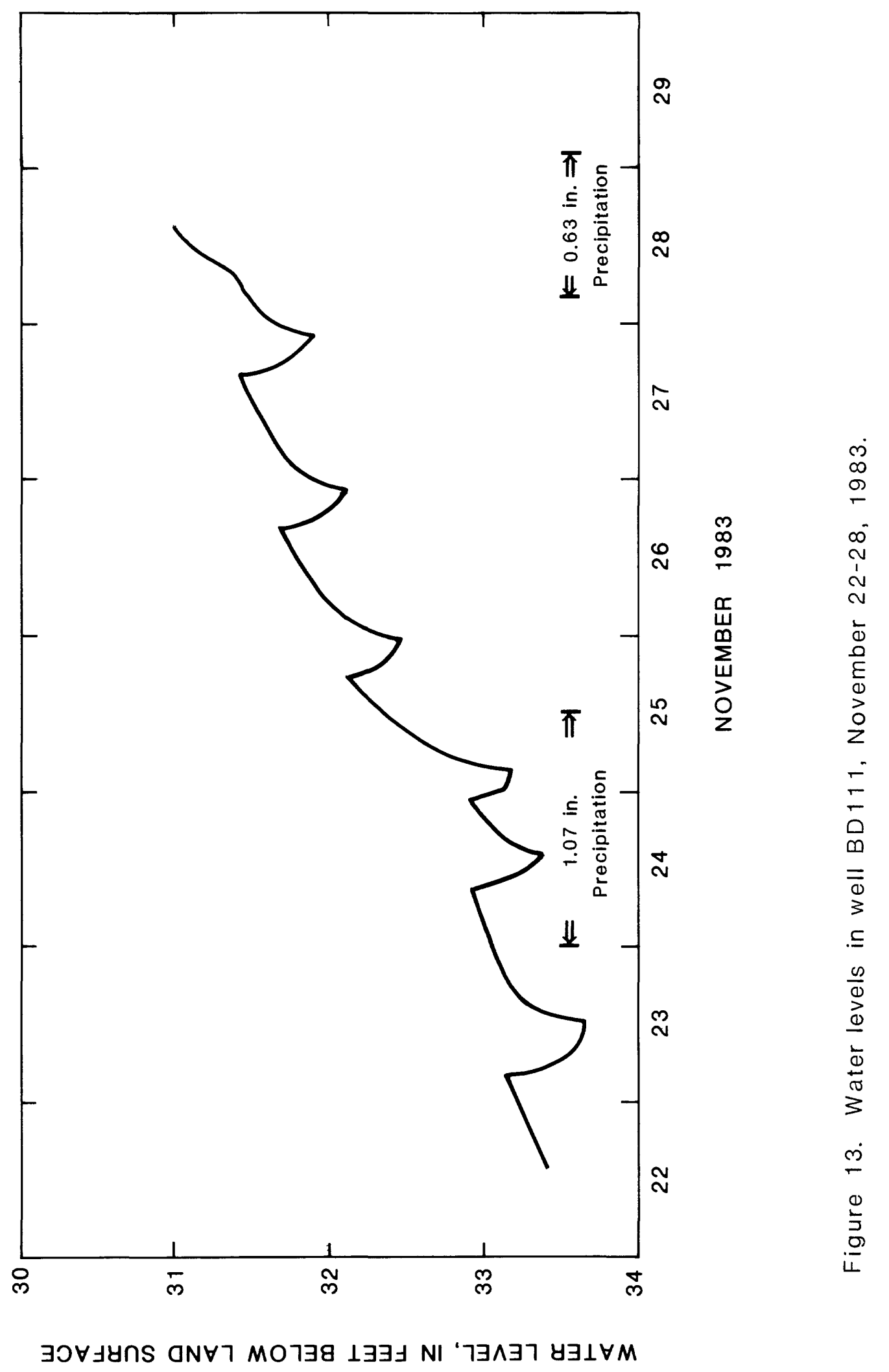




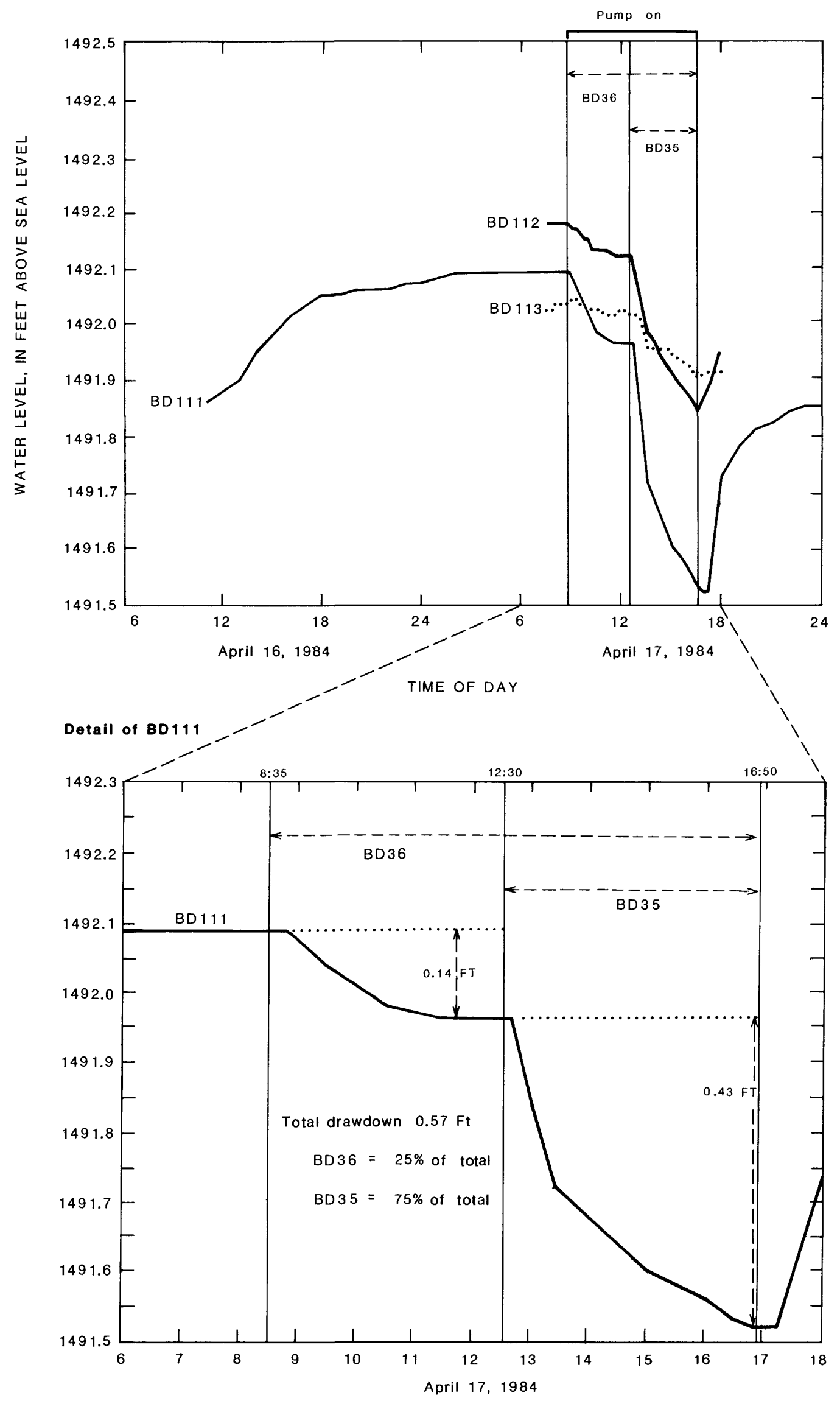

Figure 14. Water levels at Camp Round Meadow observation wells during aquifer test, April 16-17, 1984. 


\section{Sampling Strategy}

A two-phase approach was used to sample and analyze water from springs, wells, and streams in the park. In phase 1 , an initial set of samples was collected to characterize the general water quality of 15 wells, 13 springs, and 7 stream sites. In phase 2, seven wells and five springs were selected for continued analysis. Samples from these sites were collected quarterly from October 1983 through December 1984.

\section{Methods of Analysis}

Wells were pumped prior to sampling to evacuate two to three wellcasing volumes of water and until $\mathrm{pH}$ and specific conductance values stabilized. Spring samples were collected directly from the spring pipe inserted 2 to $3 \mathrm{ft}$ into the ground near the spring outlet. Streams were grab-sampled near the center of the stream.

Measurements of air and water temperature, specific conductance, alkalinity, and $\mathrm{pH}$ were made in the field. Water samples were analyzed for major chemical constituents by U.S. Geological Survey laboratories in Reston, Virginia, or Atlanta, Georgia, using methods described in Skougstad and others, 1979 .

Throughout the project period, water samples were analyzed for fecalstreptococcus (FS), fecal coliform (FC), and total coliform (TC) bacteria using the membrane-filter method (American Public Health Association, 1976; and Greeson and others, 1977). In addition, selected fecal streptococcus colonies were tested to confirm that they were Streptococcus faecalis ( . faecalis) using miniaturized tests designed by Analytab Products (API 205$)^{1}$. A gelatin 1iquifaction test (Mates, 1983) was then performed on confirmed $\underline{S}$. faecalis colonies to determine if they were $S$. faecalis variety liquifaciens which has limited sanitary significance because it is not necessarily of fecal origin and may persist in water below $12^{\circ} \mathrm{C}$ (Geldreich, 1970).

\section{Chemistry}

Table 2 (p. 26) gives field measurements of properties, laboratorydetermined concentrations of major chemical constituents, and biological results for water samples collected throughout the park during the study period. Figure 15 relates calcium concentration to alkalinity, and figure 16 relates chloride concentration to nitrite plus nitrate concentration. Median seasonal values derived from data in table 2 are plotted. Sample sizes for the median seasonal value range from one to four. During periods

${ }^{1}$ Use of brand names in this report is for descriptive purposes only and does not constitute endorsement by the U.S. Geological Survey. 
when more than one sample was collected, the median was calculated progressively for each day, then each week, month, and season. Seasons were represented as follows:

$\begin{array}{ll}\text { Winter: } & \text { January - March } \\ \text { Spring: } & \text { April - June } \\ \text { Summer: } & \text { July - September } \\ \text { Autumn: } & \text { October - December }\end{array}$

None of the sample concentrations measured during the study (table 2) exceeded the U.S. Environmental Protection Agency standards for drinking water (1976). The maximum recommended chloride concentration is $250 \mathrm{mg} / \mathrm{L}$; above this level, water tastes salty. This is almost two and one-half times the maximum level measured in the park's water. The maximum recommended nitrite plus nitrate (as $N$ ) concentration for drinking water is $10 \mathrm{mg} / \mathrm{L}$ or almost twice the maximum level measured in the park. On the other hand, just because these sites do not exceed standards now, does not mean that they will not do so in the future.

Two reaction lines are shown in figure 15 representing reactions of calcium carbonate with ionic hydrogen and with carbonic acid. The principal reaction appears to be with ionic hydrogen, which may be partially derived from acid precipitation (Katz and others, 1985).

Figure 16 is divided arbitrarily into six types based on the degree of contamination by chloride and nitrite plus nitrate from various sources for wells, springs, and streams in the park. Chloride can be used as an indicator of road salt. Nitrite plus nitrate (as $N$ ) chloride can be used as an indicator of septic contamination. Sources of fecal contamination may be human or animal. Human septic sources are indicated by elevated nitrite plus nitrate and chloride concentrations, and the proximity of sewage treatment facilities. Animal sources are indicated by elevated nitrite plus nitrate concentrations in areas with no sewage treatment facilities nearby. A lack of fecal bacteria in samples may be misleading because they may be filtered out by the soils.

Natural water (type I) consists of well and spring samples where nattural weathering of soil and rocks is believed to be the primary source of chloride and nitrite plus nitrate in the water. These conditions generally exist at wooded sites, well away from salted roads and septic systems. Maximum concentrations are $3 \mathrm{mg} / \mathrm{L}$ and $0.3 \mathrm{mg} / \mathrm{L}$ for chloride and nitrite plus nitrate, respectively. Samples of this type are from the "Jim Brown" wells, from wells at Camp Misty Mount (BD 7, BD 8) and Camp Peniel (BD 49), and one spring sample from Owens Creek campground (BD 73).

The low-chloride, intermediate nitrite-plus-nitrate water (type II) contains chloride concentrations of less than $3 \mathrm{mg} / \mathrm{L}$, and nitrite plus nitrate concentrations ranging from $0.3 \mathrm{mg} / \mathrm{L}$ to $2 \mathrm{mg} / \mathrm{L}$ (as $\mathrm{N}$ ). These sites, also in wooded areas, may be affected by animal waste and decaying plant and animal matter. This type includes well samples from Camp Peniel (BD 49), Poplar Grove (BD 40, BD 41), and one from the "Jim Brown" observation well (BD 44). Samples from springs include those from the Lantz spring (AD 1), 


\begin{tabular}{|c|c|c|c|c|c|c|c|c|c|c|}
\hline $\begin{array}{l}\text { LOCAL } \\
\text { IDEN- } \\
\text { TI- } \\
\text { FIER }\end{array}$ & $\begin{array}{c}\text { DATE } \\
\text { OF } \\
\text { SAMPLE }\end{array}$ & TIME & $\begin{array}{c}\text { TEMPER- } \\
\text { ATURE, } \\
\text { AIR } \\
\text { (DEG C) }\end{array}$ & $\begin{array}{l}\text { TEMPER- } \\
\text { ATURE } \\
\text { (DEG C) }\end{array}$ & $\begin{array}{l}\text { SPE- } \\
\text { CIFIC } \\
\text { CON- } \\
\text { DUCT- } \\
\text { ANCE } \\
\text { (UNHOS) }\end{array}$ & $\begin{array}{c}\text { PH } \\
\text { ( STAND- } \\
\text { ARD } \\
\text { UNITS) }\end{array}$ & $\begin{array}{l}\text { COLI- } \\
\text { FORM, } \\
\text { FECAL, } \\
0.7 \\
\text { UM-MF } \\
(\text { COLS.I } \\
100 \mathrm{ML})\end{array}$ & $\begin{array}{l}\text { COLI- } \\
\text { FORM, } \\
\text { TOTAL, } \\
\text { IMMED. } \\
\text { MEM.FIL } \\
\text { (COLS./ } \\
100 \mathrm{ML} \text { ) }\end{array}$ & $\begin{array}{c}\text { STREP- } \\
\text { TOCOCCI } \\
\text { FECAL, } \\
\text { KF AGAR } \\
\text { (COLS. } \\
\text { PER } \\
100 \mathrm{ML})\end{array}$ & $\begin{array}{l}\text { HARD- } \\
\text { NESS } \\
\text { (MG/L } \\
\text { AS } \\
\text { CAC03) }\end{array}$ \\
\hline
\end{tabular}

WELL

\begin{tabular}{|c|c|c|c|c|c|c|c|c|c|c|c|}
\hline BD & 6 & $\begin{array}{l}83-04-26 \\
83-06-06\end{array}$ & $\begin{array}{l}1300 \\
1345\end{array}$ & $\begin{array}{l}22.0 \\
24.0\end{array}$ & $\begin{array}{l}9.0 \\
9.0\end{array}$ & $\begin{array}{l}150 \\
245\end{array}$ & $\begin{array}{l}5.8 \\
5.8\end{array}$ & $\begin{array}{l}<1 \\
<1\end{array}$ & - & $\begin{array}{r}15 \\
>200\end{array}$ & $\begin{array}{l}68 \\
66\end{array}$ \\
\hline BD & 7 & $\begin{array}{l}83-04-25 \\
83-06-02\end{array}$ & $\begin{array}{l}1215 \\
1300\end{array}$ & $\begin{array}{r}5.0 \\
17.0\end{array}$ & $\begin{array}{l}11.0 \\
11.0\end{array}$ & $\begin{array}{l}46 \\
51\end{array}$ & $\begin{array}{l}6.1 \\
6.4\end{array}$ & $\begin{array}{l}<1 \\
<1\end{array}$ & -- & $\begin{array}{l}3 \\
4\end{array}$ & $\begin{array}{l}18 \\
23\end{array}$ \\
\hline \multirow[t]{2}{*}{ BD } & 8 & $\begin{array}{l}83-04-25 \\
83-06-02 \\
83-07-25 \\
83-11-04\end{array}$ & $\begin{array}{l}1100 \\
1115 \\
1140 \\
1130\end{array}$ & $\begin{array}{r}3.0 \\
17.0 \\
22.0 \\
3.0\end{array}$ & $\begin{array}{r}9.0 \\
10.0 \\
11.0 \\
8.0\end{array}$ & $\begin{array}{l}47 \\
59 \\
46 \\
46\end{array}$ & $\begin{array}{l}6.1 \\
6.4 \\
5.6 \\
6.4\end{array}$ & $\begin{array}{l}<1 \\
<1 \\
<1 \\
<1\end{array}$ & $\begin{array}{l}- \\
- \\
<1\end{array}$ & $\begin{array}{l}23 \\
<1 \\
36 \\
<1\end{array}$ & $\begin{array}{l}19 \\
25 \\
18 \\
26\end{array}$ \\
\hline & & $\begin{array}{l}84-03-07 \\
84-05-09 \\
84-08-08 \\
84-11-29\end{array}$ & $\begin{array}{l}1100 \\
1310 \\
0930 \\
1500\end{array}$ & $\begin{array}{r}-1.0 \\
12.0 \\
25.0 \\
5.0\end{array}$ & $\begin{array}{r}9.0 \\
10.0 \\
13.5 \\
11.0\end{array}$ & $\begin{array}{l}75 \\
45 \\
52 \\
51\end{array}$ & $\begin{array}{l}6.4 \\
6.2 \\
5.8 \\
6.2\end{array}$ & $\begin{array}{l}<1 \\
<1 \\
<1 \\
<1\end{array}$ & $\begin{array}{l}<1 \\
<1 \\
<1 \\
<1\end{array}$ & $\begin{array}{l}<1 \\
<1 \\
<1 \\
<1\end{array}$ & $\begin{array}{l}30 \\
18 \\
20 \\
22\end{array}$ \\
\hline BD & 34 & $\begin{array}{l}83-06-02 \\
83-07-13\end{array}$ & $\begin{array}{l}0930 \\
1115\end{array}$ & $\begin{array}{l}14.0 \\
26.0\end{array}$ & $\begin{array}{l}11.0 \\
12.5\end{array}$ & $\begin{array}{l}163 \\
168\end{array}$ & $\begin{array}{l}6.9 \\
6.6\end{array}$ & $\begin{array}{l}<1 \\
<1\end{array}$ & $\overline{<1}$ & $\begin{array}{r}1 \\
<1\end{array}$ & $\begin{array}{l}69 \\
68\end{array}$ \\
\hline \multirow[t]{3}{*}{$\mathrm{BD}$} & 35 & $\begin{array}{l}83-05-03 \\
83-06-13 \\
83-07-19 \\
83-10-31 \\
83-11-01\end{array}$ & $\begin{array}{l}1315 \\
1000 \\
1115 \\
1430 \\
1200\end{array}$ & $\begin{array}{r}18.0 \\
25.5 \\
-5 \\
17.0 \\
15.0\end{array}$ & $\begin{array}{r}15.0 \\
13.0 \\
-\overrightarrow{8.0} \\
15.0\end{array}$ & $\begin{array}{l}200 \\
206 \\
230 \\
221 \\
220\end{array}$ & $\begin{array}{l}5.5 \\
5.4 \\
5.6 \\
5.9 \\
6.2\end{array}$ & $\begin{array}{l}<1 \\
<1 \\
<1 \\
<1 \\
<1\end{array}$ & $\begin{array}{l}- \\
- \\
<1 \\
<1 \\
<1\end{array}$ & $\begin{array}{l}<1 \\
<1 \\
<1 \\
<1 \\
<1\end{array}$ & $\begin{array}{l}49 \\
60 \\
55 \\
74 \\
85\end{array}$ \\
\hline & & $\begin{array}{l}84-03-06 \\
84-03-08 \\
84-03-20 \\
84-03-30 \\
84-04-10\end{array}$ & $\begin{array}{l}0950 \\
0900 \\
0830 \\
0915 \\
1000\end{array}$ & $\begin{array}{r}.0 \\
.0 \\
5.0 \\
.0 \\
5.0\end{array}$ & $\begin{array}{l}10.0 \\
10.0 \\
13.0 \\
10.0 \\
10.0\end{array}$ & $\begin{array}{l}201 \\
194 \\
195 \\
158 \\
243\end{array}$ & $\begin{array}{l}5.8 \\
5.7 \\
6.0 \\
5.9 \\
5.9\end{array}$ & $\begin{array}{l}<1 \\
-<1 \\
<1 \\
<1\end{array}$ & $\begin{array}{l}<1 \\
-<1 \\
<1 \\
<1\end{array}$ & $\begin{array}{l}<1 \\
-<1 \\
<1 \\
<1\end{array}$ & $\begin{array}{l}62 \\
-- \\
64 \\
60 \\
58\end{array}$ \\
\hline & & $\begin{array}{l}84-04-17 \\
84-04-24 \\
84-05-10 \\
84-08-07 \\
84-12-04\end{array}$ & $\begin{array}{l}1230 \\
1315 \\
1015 \\
1150 \\
0915\end{array}$ & $\begin{array}{r}15.0 \\
6.0 \\
10.0 \\
27.0 \\
10.0\end{array}$ & $\begin{array}{l}13.0 \\
17.0 \\
11.0 \\
13.5 \\
11.0\end{array}$ & $\begin{array}{l}245 \\
375 \\
202 \\
285 \\
221\end{array}$ & $\begin{array}{l}5.7 \\
6.4 \\
5.5 \\
5.7 \\
5.9\end{array}$ & $\begin{array}{l}<1 \\
<1 \\
<1 \\
<1 \\
<1\end{array}$ & $\begin{array}{l}<1 \\
<1 \\
<1 \\
<1 \\
<1\end{array}$ & $\begin{array}{r}>200 \\
<1 \\
<1 \\
<1 \\
<1\end{array}$ & $\begin{array}{l}62 \\
60 \\
64 \\
75 \\
83\end{array}$ \\
\hline \multirow[t]{3}{*}{ BD } & 36 & $\begin{array}{l}83-05-03 \\
83-06-13 \\
83-07-19 \\
83-10-31 \\
83-11-01\end{array}$ & $\begin{array}{l}1230 \\
1005 \\
1130 \\
1435 \\
1205\end{array}$ & $\begin{array}{r}18.0 \\
25.5 \\
-\overline{-} \\
17.0 \\
14.0\end{array}$ & $\begin{array}{r}13.0 \\
13.0 \\
-\overline{8.0} \\
15.0\end{array}$ & $\begin{array}{l}205 \\
205 \\
200 \\
189 \\
176\end{array}$ & $\begin{array}{l}6.0 \\
6.2 \\
5.9 \\
6.3 \\
6.3\end{array}$ & $\begin{array}{l}<1 \\
<1 \\
<1 \\
<1 \\
<1\end{array}$ & $\begin{array}{l}-- \\
- \\
<1 \\
<1 \\
<1\end{array}$ & $\begin{array}{r}>200 \\
<1 \\
<1 \\
<1 \\
<1\end{array}$ & $\begin{array}{l}72 \\
77 \\
86 \\
69 \\
71\end{array}$ \\
\hline & & $\begin{array}{l}84-03-06 \\
84-03-08 \\
84-03-20 \\
84-03-30 \\
84-04-10\end{array}$ & $\begin{array}{l}0947 \\
1015 \\
0915 \\
0930 \\
1010\end{array}$ & $\begin{array}{r}.0 \\
-4.0 \\
5.0 \\
.0 \\
5.0\end{array}$ & $\begin{array}{l}10.0 \\
10.0 \\
12.5 \\
10.0 \\
10.0\end{array}$ & $\begin{array}{l}445 \\
255 \\
226 \\
172 \\
285\end{array}$ & $\begin{array}{l}7.9 \\
6.5 \\
6.5 \\
6.7 \\
6.7\end{array}$ & $\begin{array}{l}<1 \\
<1 \\
<1 \\
<1 \\
<1\end{array}$ & $\begin{array}{l}<1 \\
<1 \\
<1 \\
<1 \\
<1\end{array}$ & $\begin{array}{l}<1 \\
<1 \\
<1 \\
<1 \\
<1\end{array}$ & $\begin{array}{r}98 \\
110 \\
94 \\
93 \\
120\end{array}$ \\
\hline & & $\begin{array}{l}84-04-17 \\
84-04-24 \\
84-05-10 \\
84-08-07 \\
84-12-04\end{array}$ & $\begin{array}{l}1235 \\
1300 \\
1030 \\
1145 \\
0930\end{array}$ & $\begin{array}{r}15.0 \\
6.0 \\
10.0 \\
27.0 \\
10.0\end{array}$ & $\begin{array}{l}13.0 \\
17.0 \\
11.0 \\
13.0 \\
11.0\end{array}$ & $\begin{array}{l}260 \\
450 \\
203 \\
280 \\
224\end{array}$ & $\begin{array}{l}6.4 \\
7.1 \\
6.3 \\
6.4 \\
6.4\end{array}$ & $\begin{array}{l}<1 \\
-<1 \\
<1 \\
<1\end{array}$ & $\begin{array}{l}<1 \\
-- \\
<1 \\
<1 \\
<1\end{array}$ & $\begin{array}{l}<1 \\
-<1 \\
<1 \\
<1\end{array}$ & $\begin{array}{l}99 \\
78 \\
93 \\
95 \\
96\end{array}$ \\
\hline
\end{tabular}




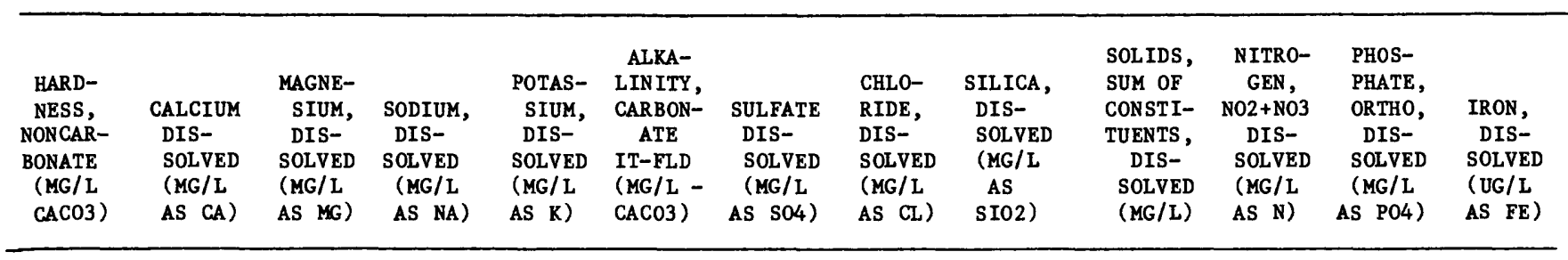

SAMPLES

\begin{tabular}{|c|c|c|c|c|c|c|c|c|c|c|c|c|}
\hline $\begin{array}{l}49 \\
47\end{array}$ & $\begin{array}{l}14 \\
13\end{array}$ & $\begin{array}{l}8.2 \\
8.2\end{array}$ & $\begin{array}{l}13 \\
16\end{array}$ & $\begin{array}{r}1.0 \\
.84\end{array}$ & $\begin{array}{l}19 \\
20\end{array}$ & $\begin{array}{l}5.9 \\
6.0\end{array}$ & $\begin{array}{l}32 \\
20\end{array}$ & $\begin{array}{l}-- \\
--\end{array}$ & -- & $\begin{array}{l}1.2 \\
1.2\end{array}$ & .09 & - \\
\hline $\begin{array}{l}0 \\
0\end{array}$ & $\begin{array}{l}3.1 \\
4.7\end{array}$ & $\begin{array}{l}2.6 \\
2.8\end{array}$ & $\begin{array}{l}1.7 \\
1.7\end{array}$ & $\begin{array}{l}.42 \\
.39\end{array}$ & $\begin{array}{l}22 \\
--\end{array}$ & $\begin{array}{l}.1 \\
.1\end{array}$ & $\begin{array}{l}1.5 \\
1.3\end{array}$ & -- & - & $\begin{array}{l}.04 \\
.05\end{array}$ &.$\overline{11}$ & -- \\
\hline $\begin{array}{l}0 \\
0 \\
0 \\
1\end{array}$ & $\begin{array}{l}3.2 \\
4.0 \\
3.1 \\
4.4\end{array}$ & $\begin{array}{l}2.6 \\
3.6 \\
2.5 \\
3.6\end{array}$ & $\begin{array}{l}1.7 \\
2.1 \\
2.0 \\
2.5\end{array}$ & $\begin{array}{l}.30 \\
.36 \\
.45 \\
.30\end{array}$ & $\begin{array}{l}21 \\
-- \\
19 \\
25\end{array}$ & $\begin{array}{r}.4 \\
1.9 \\
.2 \\
1.8\end{array}$ & $\begin{array}{l}3.6 \\
2.3 \\
2.4 \\
4.3\end{array}$ & $\begin{array}{l}-- \\
-- \\
-- \\
13\end{array}$ & $\begin{array}{l}-- \\
-- \\
--\end{array}$ & $\begin{array}{l}.10 \\
.11 \\
.10 \\
.15\end{array}$ & $\begin{array}{l}.0 \\
.09 \\
.18 \\
.71\end{array}$ & $\begin{array}{l}-- \\
-- \\
- \\
<3\end{array}$ \\
\hline $\begin{array}{l}0 \\
0 \\
0 \\
2\end{array}$ & $\begin{array}{l}5.1 \\
3.1 \\
3.3 \\
3.7\end{array}$ & $\begin{array}{l}4.3 \\
2.6 \\
2.8 \\
3.1\end{array}$ & $\begin{array}{l}2.4 \\
1.5 \\
1.6 \\
1.9\end{array}$ & $\begin{array}{l}.30 \\
.30 \\
.30 \\
.30\end{array}$ & $\begin{array}{l}31 \\
20 \\
21 \\
20\end{array}$ & $\begin{array}{r}3.5 \\
.8 \\
.7 \\
1.0\end{array}$ & $\begin{array}{l}2.6 \\
2.2 \\
2.5 \\
2.3\end{array}$ & $\begin{array}{l}13 \\
11 \\
12 \\
13\end{array}$ & $\begin{array}{l}50 \\
33 \\
36 \\
37\end{array}$ & $\begin{array}{r}.24 \\
.11 \\
.13 \\
.15\end{array}$ & $\begin{array}{r}.06 \\
- \\
.18 \\
.06\end{array}$ & $\begin{array}{r}11 \\
6 \\
17 \\
3\end{array}$ \\
\hline $\begin{array}{r}15 \\
4\end{array}$ & $\begin{array}{l}11 \\
11\end{array}$ & $\begin{array}{l}10 \\
10\end{array}$ & $\begin{array}{l}6.0 \\
6.1\end{array}$ & $\begin{array}{l}.30 \\
.42\end{array}$ & $-\overline{65}$ & $\begin{array}{l}2.4 \\
2.4\end{array}$ & $\begin{array}{l}13 \\
16\end{array}$ & -- & -- & $\begin{array}{l}.09 \\
.20\end{array}$ & -- & -- \\
\hline $\begin{array}{l}27 \\
33 \\
16 \\
38 \\
34\end{array}$ & $\begin{array}{l}12 \\
15 \\
11 \\
20 \\
24\end{array}$ & $\begin{array}{l}4.8 \\
5.6 \\
6.6 \\
5.9 \\
6.0\end{array}$ & $\begin{array}{r}10 \\
12 \\
11 \\
10 \\
8.9\end{array}$ & $\begin{array}{l}2.1 \\
1.6 \\
1.0 \\
1.6 \\
1.6\end{array}$ & $\begin{array}{l}22 \\
27 \\
39 \\
36 \\
51\end{array}$ & $\begin{array}{l}7.1 \\
6.0 \\
5.3 \\
6.2 \\
6.6\end{array}$ & $\begin{array}{l}17 \\
19 \\
16 \\
31 \\
26\end{array}$ & $\begin{array}{l}-- \\
-- \\
-- \\
18 \\
27\end{array}$ & $\begin{array}{r}-- \\
-- \\
110 \\
130\end{array}$ & $\begin{array}{l}3.6 \\
4.3 \\
4.1 \\
3.9 \\
3.7\end{array}$ & $\begin{array}{l}-- \\
.80 \\
.18 \\
.09 \\
.03\end{array}$ & $\begin{array}{l}-- \\
-- \\
-- \\
30 \\
36\end{array}$ \\
\hline 26 & 15 & 5.9 & 12 & 1.8 & 36 & 6.5 & 35 & 14 & 110 & 3.6 & - & 130 \\
\hline $\begin{array}{l}-- \\
28 \\
37 \\
18\end{array}$ & $\begin{array}{l}-- \\
17 \\
14 \\
13\end{array}$ & $\begin{array}{l}-- \\
5.2 \\
6.1 \\
6.2\end{array}$ & $\begin{array}{l}-- \\
10 \\
12 \\
22\end{array}$ & $\begin{array}{l}-- \\
1.9 \\
1.9 \\
2.0\end{array}$ & $\begin{array}{l}-- \\
36 \\
23 \\
40\end{array}$ & $\begin{array}{l}-- \\
6.5 \\
5.8 \\
8.6\end{array}$ & $\begin{array}{l}-- \\
29 \\
38 \\
39\end{array}$ & $\begin{array}{l}-- \\
17 \\
14 \\
12\end{array}$ & $\begin{array}{l}-- \\
110 \\
110 \\
130\end{array}$ & $\begin{array}{l}-- \\
3.4 \\
3.8 \\
3.4\end{array}$ & $\begin{array}{l}-- \\
-- \\
-- \\
--\end{array}$ & $\begin{array}{r}-- \\
710 \\
33 \\
250\end{array}$ \\
\hline $\begin{array}{r}39 \\
0 \\
45 \\
55 \\
38\end{array}$ & $\begin{array}{l}14 \\
15 \\
15 \\
18 \\
23\end{array}$ & $\begin{array}{l}6.5 \\
5.4 \\
6.5 \\
7.3 \\
6.2\end{array}$ & $\begin{array}{l}15 \\
53 \\
13 \\
12 \\
13\end{array}$ & $\begin{array}{l}2.0 \\
1.9 \\
2.0 \\
1.9 \\
1.5\end{array}$ & $\begin{array}{r}23 \\
119 \\
19 \\
20 \\
45\end{array}$ & $\begin{array}{l}8.9 \\
8.1 \\
5.1 \\
6.9 \\
6.8\end{array}$ & $\begin{array}{l}41 \\
37 \\
42 \\
45 \\
33\end{array}$ & $\begin{array}{l}12 \\
14 \\
13 \\
15 \\
17\end{array}$ & $\begin{array}{l}110 \\
210 \\
110 \\
120 \\
130\end{array}$ & $\begin{array}{l}3.0 \\
3.4 \\
3.3 \\
3.6 \\
3.5\end{array}$ & $\begin{array}{l}-- \\
-- \\
-- \\
--\end{array}$ & $\begin{array}{r}180 \\
160 \\
45 \\
45 \\
54\end{array}$ \\
\hline $\begin{array}{l}15 \\
14 \\
28 \\
45 \\
17\end{array}$ & $\begin{array}{l}23 \\
25 \\
29 \\
22 \\
24\end{array}$ & $\begin{array}{l}3.5 \\
3.2 \\
3.0 \\
3.3 \\
2.8\end{array}$ & $\begin{array}{l}9.6 \\
8.5 \\
8.9 \\
8.8 \\
6.6\end{array}$ & $\begin{array}{l}2.2 \\
1.4 \\
1.6 \\
1.5 \\
1.3\end{array}$ & $\begin{array}{l}57 \\
62 \\
58 \\
50 \\
54\end{array}$ & $\begin{array}{l}3.3 \\
4.0 \\
2.0 \\
2.5 \\
2.3\end{array}$ & $\begin{array}{l}4.3 \\
11 \\
14 \\
18 \\
13\end{array}$ & $\begin{array}{l}-- \\
-- \\
-- \\
17 \\
18\end{array}$ & $\begin{array}{r}-- \\
-- \\
-- \\
88 \\
100\end{array}$ & $\begin{array}{l}3.0 \\
3.3 \\
2.5 \\
2.7 \\
2.8\end{array}$ & $\begin{array}{r}.02 \\
.14 \\
-18 \\
.18 \\
.06\end{array}$ & $\begin{array}{r}-- \\
-- \\
11 \\
6\end{array}$ \\
\hline $\begin{array}{r}0 \\
25 \\
26 \\
22 \\
20\end{array}$ & $\begin{array}{l}32 \\
36 \\
31 \\
31 \\
43\end{array}$ & $\begin{array}{l}4.4 \\
4.4 \\
4.1 \\
3.8 \\
4.0\end{array}$ & $\begin{array}{r}65 \\
9.5 \\
7.5 \\
7.0 \\
7.5\end{array}$ & $\begin{array}{l}1.6 \\
1.5 \\
1.6 \\
1.5 \\
1.4\end{array}$ & $\begin{array}{r}209 \\
83 \\
68 \\
71 \\
104\end{array}$ & $\begin{array}{l}5.5 \\
5.8 \\
6.5 \\
5.4 \\
6.9\end{array}$ & $\begin{array}{l}24 \\
25 \\
21 \\
19 \\
19\end{array}$ & $\begin{array}{l}18 \\
18 \\
18 \\
18 \\
20\end{array}$ & $\begin{array}{l}280 \\
150 \\
130 \\
130 \\
160\end{array}$ & $\begin{array}{l}3.0 \\
3.2 \\
3.3 \\
3.3 \\
3.1\end{array}$ & $\begin{array}{c}.03 \\
-- \\
-- \\
- \\
--\end{array}$ & $\begin{array}{r}190 \\
76 \\
370 \\
34 \\
320\end{array}$ \\
\hline $\begin{array}{r}25 \\
0 \\
26 \\
28 \\
33\end{array}$ & $\begin{array}{l}33 \\
24 \\
31 \\
31 \\
32\end{array}$ & $\begin{array}{l}4.0 \\
4.3 \\
3.9 \\
4.2 \\
3.8\end{array}$ & $\begin{array}{c}7.3 \\
70 \\
7.1 \\
8.3 \\
8.5\end{array}$ & $\begin{array}{l}1.6 \\
1.8 \\
1.5 \\
1.6 \\
1.3\end{array}$ & $\begin{array}{r}74 \\
203 \\
68 \\
67 \\
63\end{array}$ & $\begin{array}{l}5.8 \\
5.5 \\
5.0 \\
4.3 \\
4.2\end{array}$ & $\begin{array}{l}22 \\
28 \\
21 \\
24 \\
21\end{array}$ & $\begin{array}{l}18 \\
16 \\
19 \\
18 \\
18\end{array}$ & $\begin{array}{l}140 \\
270 \\
130 \\
130 \\
130\end{array}$ & $\begin{array}{l}2.9 \\
3.3 \\
3.0 \\
3.1 \\
3.0\end{array}$ & $\begin{array}{l}-- \\
- \\
-- \\
. \\
.03\end{array}$ & $\begin{array}{r}200 \\
11 \\
75 \\
9 \\
140\end{array}$ \\
\hline
\end{tabular}




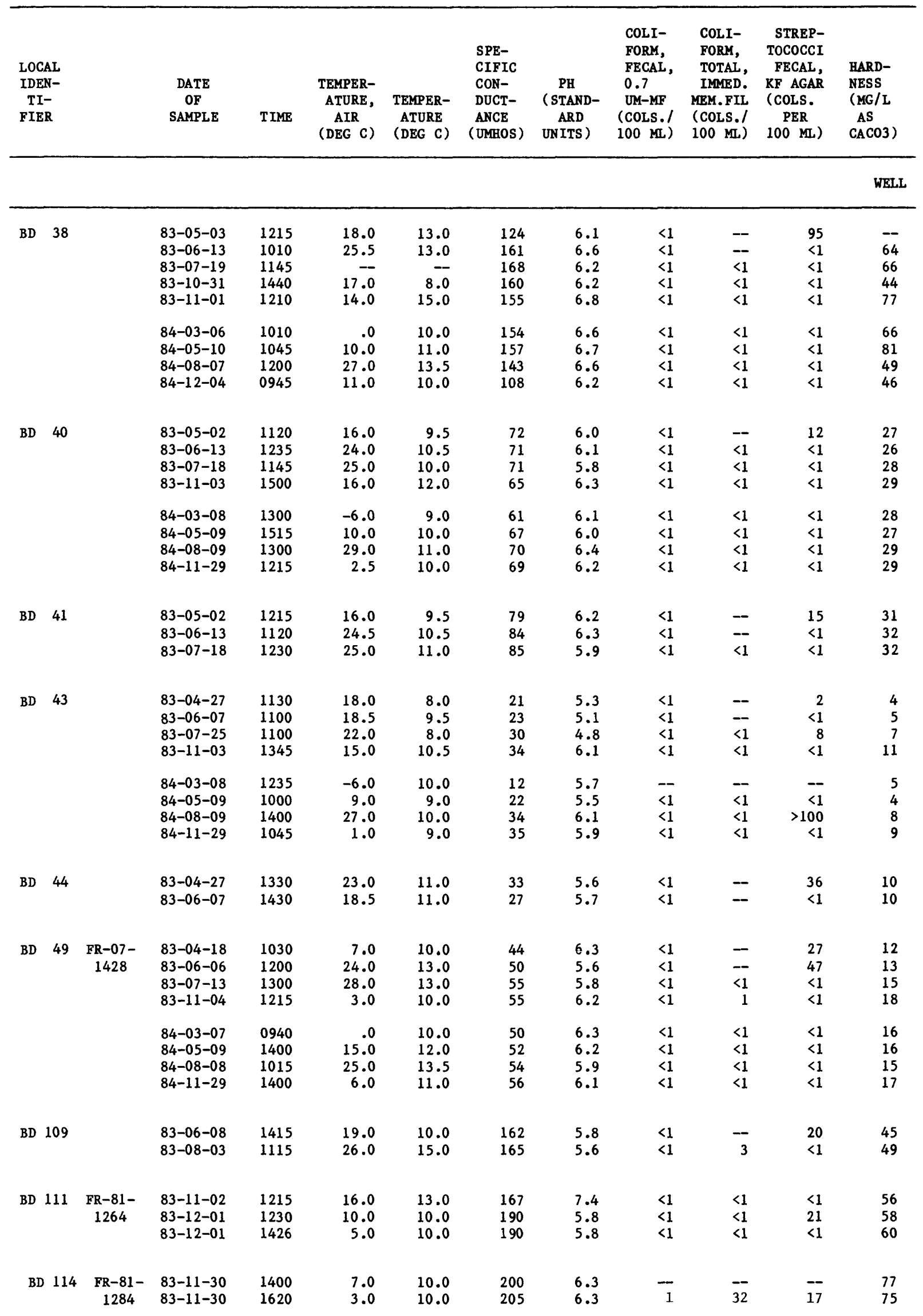




\begin{tabular}{|c|c|c|c|c|c|c|c|c|c|c|c|c|}
\hline $\begin{array}{l}\text { HARD- } \\
\text { NESS, } \\
\text { NONCAR- } \\
\text { BONATE } \\
\text { (MG/L } \\
\text { CACO3) }\end{array}$ & $\begin{array}{l}\text { CALCIUM } \\
\text { DIS- } \\
\text { SOLVED } \\
\text { (MG/L } \\
\text { AS CA) }\end{array}$ & $\begin{array}{l}\text { MAGNE- } \\
\text { SIUM, } \\
\text { DIS- } \\
\text { SOLVED } \\
\text { (MG/L } \\
\text { AS MG) }\end{array}$ & $\begin{array}{l}\text { SODIUM, } \\
\text { DIS- } \\
\text { SOLVED } \\
\text { (MG/L } \\
\text { AS NA) }\end{array}$ & $\begin{array}{l}\text { POTAS- } \\
\text { SIUM, } \\
\text { DIS- } \\
\text { SOLVED } \\
\text { (MG/L } \\
\text { AS K) }\end{array}$ & $\begin{array}{l}\text { ALKA- } \\
\text { LINITY, } \\
\text { CARBON- } \\
\text { ATE } \\
\text { IT-FLD } \\
\text { (MG/L - } \\
\text { CACO3) }\end{array}$ & $\begin{array}{l}\text { SULFATE } \\
\text { DIS- } \\
\text { SOLVED } \\
\text { (MG/L } \\
\text { AS SO4) }\end{array}$ & $\begin{array}{l}\text { CHLO- } \\
\text { RIDE, } \\
\text { DIS- } \\
\text { SOLVED } \\
\text { (MG/L } \\
\text { AS CL) }\end{array}$ & $\begin{array}{l}\text { SILICA, } \\
\text { DIS- } \\
\text { SOLVED } \\
\text { (MG/L } \\
\text { AS } \\
\text { SIO2) }\end{array}$ & $\begin{array}{l}\text { SOLIDS, } \\
\text { SUM OF } \\
\text { CONSTI- } \\
\text { TUENTS, } \\
\text { DIS- } \\
\text { SOLVED } \\
(M G / L)\end{array}$ & $\begin{array}{c}\text { NITRO- } \\
\text { GEN, } \\
\text { NO2+NO3 } \\
\text { DIS- } \\
\text { SOLVED } \\
\text { (MG/L } \\
\text { AS N) }\end{array}$ & $\begin{array}{l}\text { PHOS- } \\
\text { PHATE, } \\
\text { ORTHO, } \\
\text { DIS- } \\
\text { SOLVED } \\
\text { (MG/L } \\
\text { AS PO4) }\end{array}$ & $\begin{array}{l}\text { IRON, } \\
\text { DIS- } \\
\text { SOLVED } \\
\text { (UG/L } \\
\text { AS FE) }\end{array}$ \\
\hline
\end{tabular}

SAMPLES--Cont inued

\begin{tabular}{|c|c|c|c|c|c|c|c|c|c|c|c|c|}
\hline- & -- & -- & -- & -- & 37 & -- & -- & -- & - & -- & - & - \\
\hline 3 & 21 & 3.1 & 6.0 & 1.4 & 61 & 4.3 & 10 & -- & -- & 2.3 & -- & -- \\
\hline 6 & 21 & 3.1 & 7.7 & .96 & 61 & 4.3 & 11 & -- & - & 2.3 & -- & -- \\
\hline 6 & 13 & 2.9 & 5.4 & 1.5 & 38 & 1.8 & 7.2 & 21 & 76 & 2.5 & .06 & 11 \\
\hline 6 & 25 & 3.6 & 6.6 & 2.0 & 67 & 5.1 & 7.8 & 23 & 120 & 2.6 & .15 & 5 \\
\hline 10 & 21 & 3.3 & 5.5 & 1.8 & 57 & 3.8 & 7.0 & 22 & 98 & 2.3 & .06 & 8 \\
\hline 19 & 27 & 3.2 & 5.5 & 1.8 & 75 & 4.5 & 6.7 & 22 & 110 & 2.5 & -- & 37 \\
\hline 4 & 15 & 2.9 & 5.0 & 1.7 & 46 & 2.7 & 5.7 & 22 & 83 & 2.4 & .06 & 18 \\
\hline 9 & 14 & 2.8 & 5.1 & 1.3 & 38 & 2.4 & 7.9 & 21 & 77 & 2.3 & .03 & 180 \\
\hline 0 & 6.8 & 2.3 & 2.7 & .57 & 29 & .3 & 2.1 & -- & - & 1.7 & .05 & -- \\
\hline 1 & 6.7 & 2.2 & 2.4 & .35 & 25 & .9 & 1.5 & -- & - & 1.7 & -- & - \\
\hline 1 & 7.3 & 2.4 & 2.7 & .53 & 27 & .3 & 2.9 & -- & -- & 1.5 & .18 & -- \\
\hline 0 & 7.5 & 2.4 & 2.7 & .40 & 30 & .5 & 3.7 & 16 & 51 & $<.10$ & .12 & 240 \\
\hline 3 & 7.2 & 2.4 & 2.1 & .40 & 25 & .3 & 1.7 & 16 & 45 & 1.7 & .18 & 20 \\
\hline 1 & 7.0 & 2.4 & 2.1 & .40 & 26 & .6 & 1.3 & 15 & 45 & 1.6 & .12 & 14 \\
\hline 0 & 7.8 & 2.4 & 2.1 & .40 & 31 & 1.8 & 1.5 & 16 & 51 & 1.4 & .37 & 6 \\
\hline 5 & 7.7 & 2.4 & 2.4 & .40 & 25 & .2 & 1.9 & 16 & 46 & 1.1 & .18 & 12 \\
\hline 0 & 7.2 & 3.3 & 3.7 & .75 & 33 & .2 & 1.8 & -- & -- & 1.3 & -- & -- \\
\hline 0 & 7.4 & 3.4 & 3.0 & .57 & 34 & .8 & 2.7 & -- & - & 1.5 & .10 & -- \\
\hline 0 & 7.4 & 3.4 & 3.9 & .65 & 35 & .1 & 2.8 & -- & -- & 1.2 & .27 & -- \\
\hline 0 & 1.0 & .45 & 1.7 & .92 & 6.0 & 1.1 & 1.7 & -- & -- & .08 & -- & -- \\
\hline 0 & 1.2 & .45 & 2.4 & 1.2 & 6.0 & .4 & 1.7 & -- & -- & .08 & -- & -- \\
\hline 0 & 1.8 & .68 & 3.1 & 1.1 & 9.0 & .5 & 1.6 & -- & -- & .10 & .25 & -- \\
\hline 0 & 2.7 & 1.1 & 3.3 & .80 & 15 & .8 & 1.9 & 20 & 40 & $<.10$ & .18 & 10 \\
\hline 0 & 1.1 & .46 & 1.7 & .90 & 8.0 & 1.3 & 1.8 & 10 & 22 & .25 & -- & $<3$ \\
\hline 0 & 1.0 & .45 & 1.7 & .90 & 8.0 & .8 & 1.3 & 11 & 22 & .13 & -- & 5 \\
\hline 0 & 1.9 & .79 & 2.5 & .80 & 15 & 9.2 & 1.2 & 17 & 42 & $<.10$ & .12 & 5 \\
\hline 0 & 2.2 & .87 & 2.9 & .80 & 12 & .5 & .60 & 18 & 33 & $<.10$ & .09 & $<3$ \\
\hline 0 & 2.5 & .88 & 2.3 & .84 & 12 & .6 & 2.1 & -- & - & .59 & .20 & -- \\
\hline 4 & 2.4 & .88 & 2.4 & .84 & 6.0 & .2 & 2.1 & -- & -- & .38 & .19 & - \\
\hline 0 & 3.6 & .75 & 2.6 & 1.1 & 12 & 3.4 & 1.6 & -- & -- & .06 & -- & -- \\
\hline 0 & 3.9 & .75 & 3.0 & 1.8 & 14 & 3.9 & 1.7 & -- & -- & .08 & .44 & -- \\
\hline 0 & 4.6 & .81 & 3.8 & 1.8 & 19 & 3.3 & 2.5 & -- & -- & .02 & .36 & - \\
\hline 0 & 5.6 & .95 & 3.8 & 1.6 & 23 & 4.3 & 1.8 & 11 & 44 & .96 & .25 & 450 \\
\hline 0 & 4.8 & .88 & 2.8 & 1.6 & 21 & 3.8 & 1.3 & 10 & 39 & .20 & .37 & 420 \\
\hline 0 & 4.9 & .83 & 2.9 & 1.6 & 18 & 4.1 & 1.3 & 10 & 37 & .17 & .37 & 470 \\
\hline 0 & 4.7 & .81 & 2.7 & 1.5 & 18 & 4.4 & 1.3 & 10 & 38 & .11 & .55 & 980 \\
\hline 0 & 5.2 & .87 & 3.4 & 1.6 & 19 & 4.1 & 1.1 & 11 & 39 & $<.10$ & .34 & 480 \\
\hline 11 & 10 & 4.6 & 12 & 1.7 & 34 & 12 & 9.2 & -- & -- & 3.7 & .10 & -- \\
\hline 19 & 13 & 4.3 & 10 & 1.3 & 30 & 7.9 & 9.8 & -- & -- & 5.3 & .08 & -- \\
\hline 8 & 15 & 4.6 & 9.9 & 1.8 & 48 & 10 & 17 & 19 & 110 & 4.4 & .06 & 94 \\
\hline 26 & 15 & 4.9 & 9.8 & 1.9 & 32 & 12 & 18 & 18 & 99 & 4.4 & -- & 180 \\
\hline 29 & 16 & 4.9 & 9.9 & 1.8 & 31 & 11 & 17 & 18 & 98 & 4.3 & -- & 580 \\
\hline 34 & 19 & 7.1 & 7.3 & 2.1 & 43 & 12 & 23 & 21 & 120 & 3.5 & .03 & 74 \\
\hline 32 & 18 & 7.3 & 7.8 & 2.0 & 43 & 11 & 25 & 20 & 120 & 2.3 & .06 & 72 \\
\hline
\end{tabular}




\begin{tabular}{|c|c|c|c|c|c|c|c|c|c|c|c|}
\hline \multicolumn{2}{|c|}{$\begin{array}{l}\text { LOCAL } \\
\text { IDEN- } \\
\text { TI- } \\
\text { FIER }\end{array}$} & \multirow[t]{2}{*}{$\begin{array}{c}\text { DATE } \\
\text { OF } \\
\text { SAMPLE }\end{array}$} & \multirow[t]{2}{*}{ TIME } & \multirow[t]{2}{*}{$\begin{array}{l}\text { TEMPER- } \\
\text { ATURE, } \\
\text { AIR } \\
\text { (DEG C) }\end{array}$} & \multirow[t]{2}{*}{$\begin{array}{l}\text { TEMPER- } \\
\text { ATURE } \\
\text { (DEG C) }\end{array}$} & \multirow[t]{2}{*}{$\begin{array}{l}\text { SPE- } \\
\text { CIFIC } \\
\text { CON- } \\
\text { DUCT- } \\
\text { ANCE } \\
\text { (UMHOS) }\end{array}$} & \multirow[t]{2}{*}{$\begin{array}{c}\text { PH } \\
\text { (STAND- } \\
\text { ARD } \\
\text { UNITS) }\end{array}$} & \multirow[t]{2}{*}{$\begin{array}{l}\text { COLI- } \\
\text { FORM, } \\
\text { FECAL, } \\
0.7 \\
\text { UM-MF } \\
\text { (COLS./ } \\
100 \mathrm{ML})\end{array}$} & \multirow[t]{2}{*}{$\begin{array}{l}\text { COLI- } \\
\text { FORM, } \\
\text { TOTAL, } \\
\text { IMMED. } \\
\text { MEM.FIL } \\
\text { (COLS./ } \\
100 \mathrm{ML})\end{array}$} & \multirow[t]{2}{*}{$\begin{array}{l}\text { STREP- } \\
\text { TOCOCCI } \\
\text { FECAL, } \\
\text { KF AGAR } \\
\text { ( COLS. } \\
\text { PER } \\
100 \mathrm{ML})\end{array}$} & \multirow{2}{*}{$\begin{array}{l}\text { HARD- } \\
\text { NESS } \\
\text { (MG/L } \\
\text { AS } \\
\text { CAC03) } \\
\text { SPRIN }\end{array}$} \\
\hline & & & & & & & & & & & \\
\hline $\mathrm{AD}$ & 1 & $\begin{array}{l}83-04-12 \\
83-06-06 \\
83-07-12\end{array}$ & $\begin{array}{l}1130 \\
1200 \\
1045\end{array}$ & $\begin{array}{l}12.0 \\
24.0 \\
22.0\end{array}$ & $\begin{array}{r}10.0 \\
13.0 \\
9.5\end{array}$ & $\begin{array}{l}60 \\
68 \\
65\end{array}$ & $\begin{array}{l}5.8 \\
5.8 \\
5.6\end{array}$ & $\begin{array}{r}<1 \\
<1 \\
1\end{array}$ & $-\overline{1}$ & $\begin{array}{r}<1 \\
85 \\
4\end{array}$ & $\begin{array}{l}-\overline{20} \\
20\end{array}$ \\
\hline $\mathrm{AD} \quad 4$ & 44 & $\begin{array}{l}83-04-19 \\
83-06-07\end{array}$ & $\begin{array}{l}1215 \\
1200\end{array}$ & $\begin{array}{r}3.0 \\
19.0\end{array}$ & $\begin{array}{r}6.0 \\
12.0\end{array}$ & $\begin{array}{l}62 \\
62\end{array}$ & $\begin{array}{l}6.2 \\
5.8\end{array}$ & $\begin{array}{l}<1 \\
<1\end{array}$ & $\overline{-}$ & $\begin{array}{r}47 \\
6\end{array}$ & $\begin{array}{l}20 \\
25\end{array}$ \\
\hline BD & 3 & $\begin{array}{l}83-04-11 \\
83-06-01\end{array}$ & $\begin{array}{l}1215 \\
1330\end{array}$ & $\begin{array}{r}9.0 \\
17.0\end{array}$ & $\begin{array}{l}7.0 \\
9.0\end{array}$ & $\begin{array}{l}90 \\
80\end{array}$ & $\begin{array}{l}6.3 \\
6.3\end{array}$ & $\begin{array}{r}<1 \\
1\end{array}$ & - & $\begin{array}{l}1 \\
8\end{array}$ & $\overline{30}$ \\
\hline BD & 4 & $\begin{array}{l}83-04-11 \\
83-06-01 \\
83-07-28\end{array}$ & $\begin{array}{l}1030 \\
1410 \\
1250\end{array}$ & $\begin{array}{r}9.0 \\
17.0 \\
23.0\end{array}$ & $\begin{array}{l}8.0 \\
9.0 \\
9.0\end{array}$ & $\begin{array}{l}59 \\
55 \\
59\end{array}$ & $\begin{array}{l}6.0 \\
6.1 \\
5.8\end{array}$ & $\begin{array}{r}1 \\
<1 \\
1\end{array}$ & $-\overline{1}$ & $\begin{array}{l}<1 \\
14 \\
22\end{array}$ & $\begin{array}{l}-- \\
18 \\
19\end{array}$ \\
\hline & & $\begin{array}{l}84-03-08 \\
84-05-10 \\
84-08-09 \\
84-11-30\end{array}$ & $\begin{array}{l}1230 \\
1330 \\
1015 \\
1330\end{array}$ & $\begin{array}{l}-5.0 \\
16.5 \\
28.0 \\
11.0\end{array}$ & $\begin{array}{r}7.0 \\
10.0 \\
12.0 \\
8.5\end{array}$ & $\begin{array}{l}57 \\
60 \\
66 \\
65\end{array}$ & $\begin{array}{l}5.9 \\
6.0 \\
6.0 \\
5.9\end{array}$ & $\begin{array}{r}<1 \\
<1 \\
2 \\
1\end{array}$ & $\begin{array}{l}<1 \\
<1 \\
33 \\
30\end{array}$ & $\begin{array}{l}<1 \\
<1 \\
46 \\
<1\end{array}$ & $\begin{array}{l}19 \\
19 \\
22 \\
22\end{array}$ \\
\hline BD 39 & & $\begin{array}{l}83-05-09 \\
83-06-14 \\
83-07-28 \\
83-11-02\end{array}$ & $\begin{array}{l}1145 \\
1230 \\
1030 \\
1000\end{array}$ & $\begin{array}{r}9.0 \\
31.0 \\
23.0 \\
15.0\end{array}$ & $\begin{array}{r}9.0 \\
10.0 \\
9.0 \\
10.5\end{array}$ & $\begin{array}{l}108 \\
112 \\
120 \\
108\end{array}$ & $\begin{array}{l}5.8 \\
5.7 \\
6.0 \\
6.2\end{array}$ & $\begin{array}{l}14 \\
<1 \\
<1 \\
<1\end{array}$ & $\begin{array}{l}- \\
<1 \\
<1 \\
<1\end{array}$ & $\begin{array}{r}94 \\
1 \\
<1 \\
<1\end{array}$ & $\begin{array}{l}38 \\
40 \\
41 \\
41\end{array}$ \\
\hline & & $\begin{array}{l}84-03-07 \\
84-05-09 \\
84-08-08 \\
84-11-30\end{array}$ & $\begin{array}{l}1230 \\
0900 \\
1200 \\
1400\end{array}$ & $\begin{array}{r}5.5 \\
9.0 \\
28.0 \\
10.0\end{array}$ & $\begin{array}{l}10.0 \\
10.0 \\
13.5 \\
11.0\end{array}$ & $\begin{array}{l}110 \\
106 \\
113 \\
122\end{array}$ & $\begin{array}{l}6.1 \\
6.3 \\
6.0 \\
5.9\end{array}$ & $\begin{array}{r}<1 \\
<1 \\
<1 \\
1\end{array}$ & $\begin{array}{l}<1 \\
<1 \\
<1 \\
<1\end{array}$ & $\begin{array}{l}<1 \\
<1 \\
<1 \\
--\end{array}$ & $\begin{array}{l}41 \\
41 \\
40 \\
44\end{array}$ \\
\hline BD 72 & 2 & $\begin{array}{l}83-05-10 \\
83-06-07 \\
83-07-12\end{array}$ & $\begin{array}{l}1040 \\
1315 \\
1200\end{array}$ & $\begin{array}{r}9.0 \\
21.0 \\
19.0\end{array}$ & $\begin{array}{r}8.0 \\
10.5 \\
11.0\end{array}$ & $\begin{array}{l}53 \\
54 \\
50\end{array}$ & $\begin{array}{l}6.2 \\
6.0 \\
6.0\end{array}$ & $\begin{array}{r}<1 \\
<1 \\
4\end{array}$ & $\overrightarrow{-}$ & $\begin{array}{r}19 \\
6 \\
<1\end{array}$ & $\begin{array}{l}20 \\
19 \\
18\end{array}$ \\
\hline BD .73 & 3 & $\begin{array}{l}83-05-10 \\
83-06-07 \\
83-07-12 \\
83-11-04\end{array}$ & $\begin{array}{l}1030 \\
1300 \\
1130 \\
1100\end{array}$ & $\begin{array}{r}9.0 \\
21.0 \\
24.5 \\
3.0\end{array}$ & $\begin{array}{r}8.0 \\
10.5 \\
11.5 \\
7.0\end{array}$ & $\begin{array}{l}75 \\
72 \\
74 \\
75\end{array}$ & $\begin{array}{l}6.2 \\
6.1 \\
5.9 \\
6.6\end{array}$ & $\begin{array}{r}<1 \\
4 \\
<1 \\
>60\end{array}$ & $\begin{array}{l}- \\
\overrightarrow{<1} \\
>80\end{array}$ & $\begin{array}{r}17 \\
140 \\
32 \\
24\end{array}$ & $\begin{array}{l}26 \\
26 \\
26 \\
29\end{array}$ \\
\hline & & $\begin{array}{l}84-03-06 \\
84-05-10 \\
84-08-08 \\
84-11-30\end{array}$ & $\begin{array}{l}1140 \\
1300 \\
1500 \\
1500\end{array}$ & $\begin{array}{l}.0 \\
16.5 \\
35.0 \\
11.0\end{array}$ & $\begin{array}{l}11.0 \\
12.0 \\
15.0 \\
11.0\end{array}$ & $\begin{array}{l}72 \\
72 \\
86 \\
83\end{array}$ & $\begin{array}{l}5.8 \\
6.0 \\
5.8 \\
6.3\end{array}$ & $\begin{array}{l}<1 \\
<1 \\
<1 \\
<1\end{array}$ & $\begin{array}{r}25 \\
52 \\
3 \\
51\end{array}$ & $\begin{array}{r}<1 \\
<1 \\
11 \\
4\end{array}$ & $\begin{array}{l}27 \\
26 \\
27 \\
30\end{array}$ \\
\hline BD 106 & & $\begin{array}{l}83-04-11 \\
83-06-01 \\
83-07-27\end{array}$ & $\begin{array}{l}1130 \\
1015 \\
1030\end{array}$ & $\begin{array}{r}-- \\
15.0 \\
23.0\end{array}$ & $\begin{array}{r}8.0 \\
9.5 \\
13.0\end{array}$ & $\begin{array}{l}52 \\
49 \\
56\end{array}$ & $\begin{array}{l}6.0 \\
5.5 \\
5.4\end{array}$ & $\begin{array}{r}<1 \\
<1 \\
4\end{array}$ & $-\overrightarrow{2}$ & $\begin{array}{r}1 \\
51 \\
2\end{array}$ & $\begin{array}{l}-25 \\
19\end{array}$ \\
\hline
\end{tabular}




\begin{tabular}{|c|c|c|c|c|c|c|c|c|c|c|c|c|}
\hline $\begin{array}{c}\text { HARD- } \\
\text { NESS, } \\
\text { NONGAR- } \\
\text { BONATE } \\
(\text { MG/L } \\
\text { CACO3) }\end{array}$ & $\begin{array}{l}\text { CALCIUM } \\
\text { DIS- } \\
\text { SOLVED } \\
\text { (MG/L } \\
\text { AS CA) }\end{array}$ & $\begin{array}{l}\text { MAGNE- } \\
\text { SIUM, } \\
\text { DIS- } \\
\text { SOLVED } \\
\text { (MG/L } \\
\text { AS MG) }\end{array}$ & $\begin{array}{l}\text { SODIUM, } \\
\text { DIS- } \\
\text { SOLVED } \\
\text { (MG/L } \\
\text { AS NA) }\end{array}$ & $\begin{array}{l}\text { POTAS- } \\
\text { SIUM, } \\
\text { DIS- } \\
\text { SOLVED } \\
(\text { KG/L } \\
\text { AS K) }\end{array}$ & $\begin{array}{l}\text { ALKA- } \\
\text { LINITY, } \\
\text { CARBON- } \\
\text { ATE } \\
\text { IT-FLD } \\
\text { (MG/L - } \\
\text { CACO3) }\end{array}$ & $\begin{array}{l}\text { SULFATE } \\
\text { DIS- } \\
\text { SOLVED } \\
\text { ( } \mathrm{MG} / \mathrm{L} \\
\text { AS SO4) }\end{array}$ & $\begin{array}{l}\text { CHLO- } \\
\text { RIDE, } \\
\text { DIS- } \\
\text { SOLVED } \\
\text { (MG/L } \\
\text { AS CL) }\end{array}$ & $\begin{array}{l}\text { SILICA, } \\
\text { DIS- } \\
\text { SOLVED } \\
\text { (MG/L } \\
\text { AS } \\
\text { SIO2) }\end{array}$ & $\begin{array}{l}\text { SOLIDS, } \\
\text { SUM OF } \\
\text { CONSTI- } \\
\text { TUENTS, } \\
\text { DIS- } \\
\text { SOLVED } \\
\text { (MG/L) }\end{array}$ & $\begin{array}{c}\text { NITRO- } \\
\text { GEN, } \\
\text { NO2+NO3 } \\
\text { DIS- } \\
\text { SOLVED } \\
\text { (MG/L } \\
\text { AS N) }\end{array}$ & $\begin{array}{c}\text { PHOS- } \\
\text { PHATE, } \\
\text { ORTHO, } \\
\text { DIS- } \\
\text { SOLVED } \\
\text { (MG/L } \\
\text { AS PO4) }\end{array}$ & $\begin{array}{l}\text { IRON, } \\
\text { DIS- } \\
\text { SOLVED } \\
\text { (UG/L } \\
\text { AS FE) }\end{array}$ \\
\hline
\end{tabular}

SAMPLES

\begin{tabular}{|c|c|c|c|c|c|c|c|c|c|c|c|c|}
\hline-- & -- & - & -- & -- & 13 & -- & -- & -- & -- & -- & -- & -- \\
\hline $\begin{array}{l}5 \\
3\end{array}$ & $\begin{array}{l}4.7 \\
4.9\end{array}$ & $\begin{array}{l}1.9 \\
1.9\end{array}$ & $\begin{array}{l}3.3 \\
3.9\end{array}$ & $\begin{array}{l}.82 \\
.94\end{array}$ & $\begin{array}{l}15 \\
17\end{array}$ & $\begin{array}{l}6.6 \\
7.3\end{array}$ & $\begin{array}{l}2.7 \\
1.7\end{array}$ & $\begin{array}{l}-- \\
--\end{array}$ & -- & $\begin{array}{l}.56 \\
.68\end{array}$ & $\begin{array}{l}.39 \\
.21\end{array}$ & -- \\
\hline $\begin{array}{r}9 \\
10\end{array}$ & $\begin{array}{l}4.2 \\
5.2\end{array}$ & $\begin{array}{l}2.3 \\
2.8\end{array}$ & $\begin{array}{l}1.8 \\
2.6\end{array}$ & $\begin{array}{l}.40 \\
.65\end{array}$ & $\begin{array}{l}11 \\
15\end{array}$ & $\begin{array}{l}6.5 \\
5.3\end{array}$ & $\begin{array}{l}1.9 \\
2.2\end{array}$ & $\begin{array}{l}-- \\
--\end{array}$ & -- & $\begin{array}{l}1.2 \\
1.5\end{array}$ & $\begin{array}{l}.21 \\
.35\end{array}$ & - \\
\hline-- & - & - & -- & - & 24 & -- & - & - & -- & - & - & - \\
\hline 6 & 7.1 & 2.9 & 3.9 & .84 & 24 & 6.1 & 2.1 & -- & -- & 1.1 & .10 & - \\
\hline- & - & -- & - & - & 11 & - & - & - & - & -- & - & - \\
\hline $\begin{array}{l}0 \\
9\end{array}$ & $\begin{array}{l}4.2 \\
4.6\end{array}$ & $\begin{array}{l}1.8 \\
1.9\end{array}$ & $\begin{array}{l}2.4 \\
2.5\end{array}$ & $\begin{array}{l}.47 \\
.53\end{array}$ & $\begin{array}{l}23 \\
11\end{array}$ & $\begin{array}{l}4.4 \\
1.8\end{array}$ & $\begin{array}{l}3.5 \\
4.6\end{array}$ & - & - & $\begin{array}{l}.76 \\
.53\end{array}$ & .07 & - \\
\hline $\begin{array}{r}9 \\
8 \\
9 \\
10\end{array}$ & $\begin{array}{l}4.6 \\
4.5 \\
5.2 \\
5.3\end{array}$ & $\begin{array}{l}1.9 \\
1.9 \\
2.1 \\
2.1\end{array}$ & $\begin{array}{l}2.1 \\
2.1 \\
2.4 \\
2.5\end{array}$ & $\begin{array}{l}.40 \\
.40 \\
.40 \\
1.1\end{array}$ & $\begin{array}{l}10 \\
11 \\
12 \\
12\end{array}$ & $\begin{array}{l}5.7 \\
5.3 \\
9.4 \\
4.8\end{array}$ & $\begin{array}{l}6.6 \\
5.0 \\
7.0 \\
5.4\end{array}$ & $\begin{array}{l}12 \\
12 \\
13 \\
13\end{array}$ & $\begin{array}{l}39 \\
38 \\
47 \\
42\end{array}$ & $\begin{array}{c}.98 \\
.93 \\
.97 \\
1.0\end{array}$ & $\begin{array}{r}.03 \\
-.15 \\
.03\end{array}$ & $\begin{array}{r}9 \\
13 \\
4 \\
7\end{array}$ \\
\hline $\begin{array}{l}10 \\
18 \\
18 \\
14\end{array}$ & $\begin{array}{l}9.3 \\
9.9 \\
10 \\
10\end{array}$ & $\begin{array}{l}3.5 \\
3.7 \\
3.7 \\
3.8\end{array}$ & $\begin{array}{l}4.8 \\
4.9 \\
5.3 \\
4.6\end{array}$ & $\begin{array}{l}.56 \\
.47 \\
.38 \\
.30\end{array}$ & $\begin{array}{l}28 \\
22 \\
23 \\
26\end{array}$ & $\begin{array}{l}4.9 \\
5.4 \\
5.6 \\
5.0\end{array}$ & $\begin{array}{l}8.5 \\
8.7 \\
6.2 \\
9.6\end{array}$ & $\begin{array}{l}-- \\
-- \\
--\end{array}$ & $\begin{array}{l}-- \\
-- \\
68\end{array}$ & $\begin{array}{l}2.4 \\
3.1 \\
3.1 \\
2.8\end{array}$ & $\begin{array}{l}-- \\
.-03 \\
.09\end{array}$ & $\begin{array}{l}-- \\
-- \\
<3\end{array}$ \\
\hline $\begin{array}{l}17 \\
17 \\
16 \\
22\end{array}$ & $\begin{array}{l}10 \\
10 \\
10 \\
11\end{array}$ & $\begin{array}{l}3.9 \\
3.9 \\
3.7 \\
4.0\end{array}$ & $\begin{array}{l}4.2 \\
4.1 \\
4.0 \\
4.3\end{array}$ & $\begin{array}{l}.40 \\
.40 \\
.40 \\
.40\end{array}$ & $\begin{array}{l}24 \\
24 \\
25 \\
22\end{array}$ & $\begin{array}{l}5.0 \\
5.4 \\
5.0 \\
5.3\end{array}$ & $\begin{array}{r}9.9 \\
9.9 \\
9.6 \\
15\end{array}$ & $\begin{array}{l}19 \\
20 \\
19 \\
20\end{array}$ & $\begin{array}{l}67 \\
68 \\
67 \\
73\end{array}$ & $\begin{array}{l}2.7 \\
2.5 \\
2.6 \\
3.3\end{array}$ & $\begin{array}{r}.06 \\
.12 \\
.06\end{array}$ & $\begin{array}{r}5 \\
7 \\
7 \\
69\end{array}$ \\
\hline $\begin{array}{l}0 \\
0\end{array}$ & $\begin{array}{l}4.6 \\
4.4\end{array}$ & $\begin{array}{l}2.1 \\
2.1\end{array}$ & $\begin{array}{l}2.8 \\
2.7\end{array}$ & $\begin{array}{l}.75 \\
.58\end{array}$ & $\begin{array}{l}20 \\
21\end{array}$ & $\begin{array}{l}2.0 \\
2.2\end{array}$ & $\begin{array}{l}2.3 \\
2.3\end{array}$ & - & -- & $\begin{array}{l}.55 \\
.46\end{array}$ & $\begin{array}{r}.04 \\
-\end{array}$ & - \\
\hline 0 & 4.1 & 2.0 & 3.0 & .81 & 19 & 2.1 & 1.7 & - & - & .53 & -- & - \\
\hline $\begin{array}{l}11 \\
10 \\
17 \\
10\end{array}$ & $\begin{array}{l}6.1 \\
5.9 \\
6.0 \\
6.7\end{array}$ & $\begin{array}{l}2.7 \\
2.7 \\
2.7 \\
3.0\end{array}$ & $\begin{array}{l}2.9 \\
3.3 \\
5.3 \\
3.8\end{array}$ & $\begin{array}{r}.84 \\
.72 \\
1.3 \\
.50\end{array}$ & $\begin{array}{l}16 \\
16 \\
17 \\
19\end{array}$ & $\begin{array}{l}6.2 \\
6.5 \\
6.0 \\
7.4\end{array}$ & $\begin{array}{l}2.2 \\
2.4 \\
2.5 \\
2.4\end{array}$ & $\begin{array}{l}-- \\
-- \\
19\end{array}$ & -- & $\begin{array}{r}2.0 \\
1.9 \\
2.4 \\
.19\end{array}$ & $\begin{array}{r}.02 \\
.52 \\
-\overline{.06}\end{array}$ & - \\
\hline $\begin{array}{r}8 \\
8 \\
12 \\
14\end{array}$ & $\begin{array}{l}6.3 \\
6.1 \\
6.3 \\
6.9\end{array}$ & $\begin{array}{l}2.7 \\
2.6 \\
2.8 \\
3.0\end{array}$ & $\begin{array}{l}2.8 \\
2.7 \\
3.1 \\
3.2\end{array}$ & $\begin{array}{l}.60 \\
.60 \\
.30 \\
.40\end{array}$ & $\begin{array}{l}19 \\
18 \\
16 \\
16\end{array}$ & $\begin{array}{l}7.1 \\
8.1 \\
6.7 \\
8.1\end{array}$ & $\begin{array}{l}2.0 \\
1.9 \\
2.3 \\
4.3\end{array}$ & $\begin{array}{l}19 \\
19 \\
20 \\
19\end{array}$ & $\begin{array}{l}52 \\
52 \\
51 \\
54\end{array}$ & $\begin{array}{l}2.3 \\
1.9 \\
2.4 \\
2.5\end{array}$ & $\begin{array}{c}-- \\
-12 \\
-\end{array}$ & $\begin{array}{r}6 \\
13 \\
5 \\
6\end{array}$ \\
\hline-- & -- & -- & - & - & 11 & - & -- & - & - & -- & - & - \\
\hline $\begin{array}{r}16 \\
9\end{array}$ & $\begin{array}{l}6.3 \\
4.5\end{array}$ & $\begin{array}{l}2.3 \\
1.8\end{array}$ & $\begin{array}{l}2.2 \\
2.5\end{array}$ & $\begin{array}{r}.48 \\
.38\end{array}$ & $\begin{array}{l}10 \\
10\end{array}$ & $\begin{array}{l}4.3 \\
4.3\end{array}$ & $\begin{array}{l}6.3 \\
6.3\end{array}$ & - & - & $\begin{array}{l}1.1 \\
1.1\end{array}$ & $\begin{array}{r}.51 \\
.46\end{array}$ & - \\
\hline
\end{tabular}


Table 2.--Water-quality data for the Catoctin Mountain National Park area, for the period 1983-84--Continued.

\begin{tabular}{|c|c|c|c|c|c|c|c|c|c|c|}
\hline $\begin{array}{l}\text { LOCAL } \\
\text { IDEN- } \\
\text { TI- } \\
\text { FIER }\end{array}$ & $\begin{array}{c}\text { DATE } \\
\text { OF } \\
\text { SAMPLE }\end{array}$ & TIME & $\begin{array}{c}\text { TEMPER- } \\
\text { ATURE, } \\
\text { AIR } \\
\text { (DEG C) }\end{array}$ & $\begin{array}{l}\text { TEMPER- } \\
\text { ATURE } \\
\text { (DEG C) }\end{array}$ & $\begin{array}{l}\text { SPE- } \\
\text { CIFIC } \\
\text { CON- } \\
\text { DUCT- } \\
\text { ANCE } \\
\text { (UMHOS) }\end{array}$ & $\begin{array}{c}\text { PH } \\
\text { (STAND- } \\
\text { ARD } \\
\text { UNITS) }\end{array}$ & $\begin{array}{l}\text { COLI- } \\
\text { FORM, } \\
\text { FECAL, } \\
0.7 \\
\text { UM-MF } \\
\text { (COLS./ } \\
100 \mathrm{ML})\end{array}$ & $\begin{array}{l}\text { COLI- } \\
\text { FORM, } \\
\text { TOTAL, } \\
\text { IMMED. } \\
\text { MEM.FIL } \\
\text { (COLS./ } \\
100 \text { ML) }\end{array}$ & $\begin{array}{c}\text { STREP- } \\
\text { TOCOCCI } \\
\text { FECAL, } \\
\text { KF AGAR } \\
\text { (COLS. } \\
\text { PER } \\
100 \text { ML) }\end{array}$ & $\begin{array}{l}\text { HARD- } \\
\text { NESS } \\
\text { (MG/L } \\
\text { AS } \\
\text { CAC03) }\end{array}$ \\
\hline & & & & & & & & & & SPRING \\
\hline \multirow[t]{2}{*}{ BD 107} & $\begin{array}{l}83-04-05 \\
83-06-01 \\
83-07-19 \\
83-11-02\end{array}$ & $\begin{array}{l}1235 \\
1115 \\
1100 \\
1600\end{array}$ & $\begin{array}{r}-- \\
19.0 \\
28.5 \\
14.0\end{array}$ & $\begin{array}{r}9.0 \\
12.5 \\
13.0 \\
15.0\end{array}$ & $\begin{array}{l}390 \\
260 \\
163 \\
171\end{array}$ & $\begin{array}{l}5.8 \\
6.2 \\
5.5 \\
6.0\end{array}$ & $\begin{array}{r}4 \\
3 \\
<1 \\
<1\end{array}$ & $\begin{array}{l}-- \\
-- \\
<1 \\
32\end{array}$ & $\begin{array}{r}8 \\
23 \\
<1 \\
6\end{array}$ & $\begin{array}{l}92 \\
16 \\
48 \\
50\end{array}$ \\
\hline & $\begin{array}{l}84-03-07 \\
84-05-09 \\
84-08-08 \\
84-11-30\end{array}$ & $\begin{array}{l}1320 \\
1115 \\
1330 \\
1015\end{array}$ & $\begin{array}{r}4.0 \\
9.0 \\
35.0 \\
7.0\end{array}$ & $\begin{array}{l}10.0 \\
13.0 \\
16.0 \\
12.0\end{array}$ & $\begin{array}{l}385 \\
300 \\
180 \\
270\end{array}$ & $\begin{array}{l}6.2 \\
6.3 \\
6.0 \\
6.2\end{array}$ & $\begin{array}{r}8 \\
6 \\
<1 \\
6\end{array}$ & $\begin{array}{r}12 \\
13 \\
1 \\
>80\end{array}$ & $\begin{array}{r}3 \\
62 \\
6 \\
--\end{array}$ & $\begin{array}{r}100 \\
81 \\
48 \\
73\end{array}$ \\
\hline \multirow[t]{2}{*}{ BD 108} & $\begin{array}{l}83-04-12 \\
83-06-08 \\
83-08-03 \\
83-11-02\end{array}$ & $\begin{array}{l}1325 \\
1030 \\
1030 \\
1125\end{array}$ & $\begin{array}{l}10.0 \\
19.0 \\
26.0 \\
17.0\end{array}$ & $\begin{array}{l}10.0 \\
14.0 \\
14.0 \\
12.5\end{array}$ & $\begin{array}{l}175 \\
150 \\
165 \\
150\end{array}$ & $\begin{array}{l}6.0 \\
6.6 \\
5.9 \\
6.7\end{array}$ & $\begin{array}{r}>60 \\
24 \\
6 \\
3\end{array}$ & $\begin{array}{r}-- \\
-- \\
>80\end{array}$ & $\begin{array}{l}76 \\
25 \\
<1 \\
21\end{array}$ & $\begin{array}{l}-- \\
46 \\
51 \\
51\end{array}$ \\
\hline & $\begin{array}{l}84-03-06 \\
84-05-08 \\
84-08-07 \\
84-11-30\end{array}$ & $\begin{array}{l}1320 \\
1400 \\
1400 \\
1115\end{array}$ & $\begin{array}{r}.0 \\
16.0 \\
31.0 \\
7.0\end{array}$ & $\begin{array}{l}12.0 \\
12.0 \\
15.0 \\
12.0\end{array}$ & $\begin{array}{l}162 \\
145 \\
155 \\
152\end{array}$ & $\begin{array}{l}6.0 \\
6.0 \\
5.9 \\
5.7\end{array}$ & $\begin{array}{l}1 \\
<1 \\
22 \\
16\end{array}$ & $\begin{array}{r}10 \\
26 \\
6 \\
>80\end{array}$ & $\begin{array}{r}3 \\
10 \\
8 \\
-\end{array}$ & $\begin{array}{l}53 \\
47 \\
48 \\
48\end{array}$ \\
\hline BD 110 & $\begin{array}{l}83-04-11 \\
83-06-01 \\
83-07-28\end{array}$ & $\begin{array}{l}1310 \\
0900 \\
1245\end{array}$ & $\begin{array}{r}9.0 \\
15.0 \\
23.0\end{array}$ & $\begin{array}{r}10.0 \\
9.5 \\
9.0\end{array}$ & $\begin{array}{l}70 \\
73 \\
77\end{array}$ & $\begin{array}{l}6.1 \\
5.7 \\
5.3\end{array}$ & $\begin{array}{l}1 \\
<1 \\
<1\end{array}$ & $\begin{array}{l}-- \\
--\end{array}$ & $\begin{array}{r}23 \\
<1 \\
7\end{array}$ & $\begin{array}{l}-- \\
72 \\
26\end{array}$ \\
\hline \multirow[t]{2}{*}{ BD 115} & $84-05-11$ & 0930 & 17.0 & 10.0 & 130 & 6.1 & $>60$ & $>80$ & $>200$ & 38 \\
\hline & & & & & & & & & & STREAM \\
\hline $\begin{array}{l}\text { Camp } 3(\text { ( ) 3-1) } \\
\text { (no. 1) }\end{array}$ & $\begin{array}{l}83-05-31 \\
83-06-14 \\
83-08-03\end{array}$ & $\begin{array}{l}1230 \\
1330 \\
1330\end{array}$ & $\begin{array}{l}15.0 . \\
31.0 \\
28.0\end{array}$ & $\begin{array}{l}12.0 \\
15.0 \\
19.0\end{array}$ & $\begin{array}{l}140 \\
150 \\
180\end{array}$ & $\begin{array}{l}6.9 \\
7.1 \\
6.9\end{array}$ & $\begin{array}{l}>60 \\
>60 \\
190\end{array}$ & $\frac{--}{146}$ & $\begin{array}{r}>200 \\
>200 \\
640\end{array}$ & $\begin{array}{l}57 \\
58 \\
57\end{array}$ \\
\hline $\begin{array}{l}\text { Camp } 3 \text { (c 3-2) } \\
\text { (no. 2) }\end{array}$ & $83-05-31$ & 1245 & 15.0 & 11.0 & 263 & 7.3 & $>60$ & -- & $>200$ & 76 \\
\hline HCPEN & $83-07-13$ & 1230 & 28.0 & 18.0 & 82 & 7.3 & 9 & 4 & 61 & 29 \\
\hline HCMM & $83-07-25$ & 1125 & 20.0 & 18.0 & 90 & 6.5 & 78 & 54 & 133 & 37 \\
\hline HCVC & $83-07-13$ & 1045 & 25.0 & 18.5 & 85 & 7.2 & 15 & $>80$ & $>800$ & 37 \\
\hline OCCG & $83-07-12$ & 1100 & 22.0 & 15.5 & 77 & 7.2 & 120 & 69 & 37 & 26 \\
\hline OCIS & $83-07-27$ & 1040 & 23.0 & 18.0 & 69 & 5.9 & 2 & 10 & 35 & 23 \\
\hline
\end{tabular}




\begin{tabular}{|c|c|c|c|c|c|c|c|c|c|c|c|c|}
\hline $\begin{array}{l}\text { HARD- } \\
\text { NESS, } \\
\text { NONCAR- } \\
\text { BONATE } \\
\text { (MG/ L } \\
\text { CACO3) }\end{array}$ & $\begin{array}{l}\text { CALCIUM } \\
\text { DIS- } \\
\text { SOLVED } \\
\text { (MG/L } \\
\text { AS CA) }\end{array}$ & $\begin{array}{l}\text { MAGNE- } \\
\text { SIUM, } \\
\text { DIS- } \\
\text { SOLVED } \\
\text { (MG/L } \\
\text { AS MG) }\end{array}$ & $\begin{array}{l}\text { SODIUM, } \\
\text { DIS- } \\
\text { SOLVED } \\
\text { (MG/L } \\
\text { AS NA) }\end{array}$ & $\begin{array}{l}\text { POTAS- } \\
\text { SIUM, } \\
\text { DIS- } \\
\text { SOLVED } \\
\text { (MG/L } \\
\text { AS K) }\end{array}$ & $\begin{array}{c}\text { ALKA- } \\
\text { LINITY, } \\
\text { CARBON- } \\
\text { ATE } \\
\text { IT-FLD } \\
(M G / L- \\
\text { CACO3) }\end{array}$ & $\begin{array}{l}\text { SULFATE } \\
\text { DIS- } \\
\text { SOLVED } \\
\text { (MG/L } \\
\text { AS SO4) }\end{array}$ & $\begin{array}{l}\text { CHLO- } \\
\text { RIDE, } \\
\text { DIS- } \\
\text { SOLVED } \\
\text { (MG/L } \\
\text { AS CL) }\end{array}$ & $\begin{array}{l}\text { SILICA, } \\
\text { DIS- } \\
\text { SOLVED } \\
\text { (MG/L } \\
\text { AS } \\
\text { SIO2) }\end{array}$ & $\begin{array}{c}\text { SOLIDS, } \\
\text { SUM OF } \\
\text { CONSTI- } \\
\text { TUENTS, } \\
\text { DIS- } \\
\text { SOLVED } \\
\text { (MG/L) }\end{array}$ & $\begin{array}{c}\text { NITRO- } \\
\text { GEN, } \\
\text { NO2+NO3 } \\
\text { DIS- } \\
\text { SOLVED } \\
\text { (MG/L } \\
\text { AS N) }\end{array}$ & $\begin{array}{l}\text { PHOS- } \\
\text { PHATE, } \\
\text { ORTHO, } \\
\text { DIS- } \\
\text { SOLVED } \\
\text { (MG/L } \\
\text { AS P04) }\end{array}$ & $\begin{array}{l}\text { IRON, } \\
\text { DIS- } \\
\text { SOLVED } \\
\text { (UG/L } \\
\text { AS FE) }\end{array}$ \\
\hline \multicolumn{13}{|l|}{ SAMPLES } \\
\hline 61 & 23 & 8.5 & 12 & 2.3 & 32 & 12 & 32 & - & - & 2.5 & - & - \\
\hline 0 & 4.0 & 1.5 & 18 & 2.3 & 34 & 7.6 & 17 & - & - & 2.4 & .15 & - \\
\hline 21 & 12 & 4.6 & 11 & 1.3 & 27 & 4.7 & 21 & -- & - & 2.4 & .27 & - \\
\hline 19 & 12 & 4.8 & 14 & 1.7 & 31 & 6.3 & 27 & 17 & 100 & 2.0 & -- & 28 \\
\hline 60 & 26 & 9.6 & 31 & 2.2 & 44 & 9.0 & 91 & 14 & 210 & 2.6 & - & $<3$ \\
\hline 38 & 20 & 7.5 & 24 & 2.0 & 43 & 12 & 55 & 14 & 160 & 2.1 & - & 12 \\
\hline 17 & 12 & 4.5 & 11 & 1.5 & 32 & 5.9 & 21 & 16 & 91 & 2.0 & .06 & 12 \\
\hline 40 & 18 & 6.8 & 22 & .50 & 33 & 9.2 & 51 & 16 & 140 & 2.0 & .03 & 4 \\
\hline-- & - & - & -- & -- & 39 & -- & -- & -- & - & -- & -- & -- \\
\hline 13 & 12 & 4.0 & 10 & 1.4 & 34 & 12 & 8.5 & - & -- & 3.5 & .09 & - \\
\hline 19 & 13 & 4.4 & 11 & 1.0 & 31 & 9.4 & 7.5 & -- & -- & 4.5 & .04 & - \\
\hline 15 & 13 & 4.6 & 11 & 1.3 & 36 & 12 & 12 & 15 & 91 & 3.8 & .12 & 11 \\
\hline 22 & 13 & 4.9 & 9.1 & 1.2 & 31 & 16 & 13 & 15 & 91 & 3.8 & .06 & 8 \\
\hline 21 & 12 & 4.2 & 8.3 & 1.1 & 26 & 14 & 13 & 15 & 83 & 3.0 & - & 14 \\
\hline 20 & 12 & 4.5 & 9.9 & 1.2 & 29 & 9.3 & 16 & 16 & 86 & 3.9 & .06 & 9 \\
\hline 20 & 12 & 4.5 & 9.8 & .60 & 25 & 10 & 14 & 16 & 82 & 2.6 & .03 & 10 \\
\hline-- & - & - & - & -- & 18 & - & -- & - & - & -- & - & -- \\
\hline 55 & 18 & 6.9 & 2.8 & .92 & 17 & 3.0 & 4.6 & -- & - & 1.8 & .14 & - \\
\hline 10 & 6.6 & 2.3 & 2.7 & 1.0 & 16 & 1.9 & 3.7 & - & -- & 1.7 & .13 & -- \\
\hline 18 & 9.6 & 3.3 & 6.8 & 1.7 & 20 & 7.8 & 11 & 14 & 66 & 3.8 & -- & 15 \\
\hline \multicolumn{13}{|l|}{ SAMPLES } \\
\hline 22 & 13 & 6.0 & 4.2 & .54 & 35 & 9.8 & 10 & - & - & .81 & .09 & - \\
\hline 23 & 13 & 6.2 & 4.8 & .72 & 35 & .7 & 1.7 & - & -- & 1.7 & -- & -- \\
\hline 17 & 16 & 4.2 & 21 & 1.9 & 40 & 18 & 18 & - & -- & 2.7 & .21 & - \\
\hline 20 & 19 & 7.0 & 21 & 1.7 & 56 & 17 & 14 & -- & -- & 2.7 & .15 & -- \\
\hline 6 & 7.7 & 2.4 & 3.6 & .60 & 22 & 5.0 & 6.9 & -- & - & .35 & .12 & - \\
\hline 7 & 8.3 & 3.9 & 3.6 & .45 & 30 & 3.8 & 7.5 & - & -- & .13 & -- & - \\
\hline 3 & 11 & 2.2 & 2.6 & .46 & 33 & 1.7 & 5.7 & - & -- & .05 & .13 & - \\
\hline 3 & 6.4 & 2.4 & 3.6 & .85 & 21 & 3.0 & 2.7 & -- & -- & .95 & .03 & - \\
\hline 12 & 5.0 & 2.6 & 3.4 & .45 & 12 & 4.2 & 6.6 & -- & -- & .59 & - & - \\
\hline
\end{tabular}




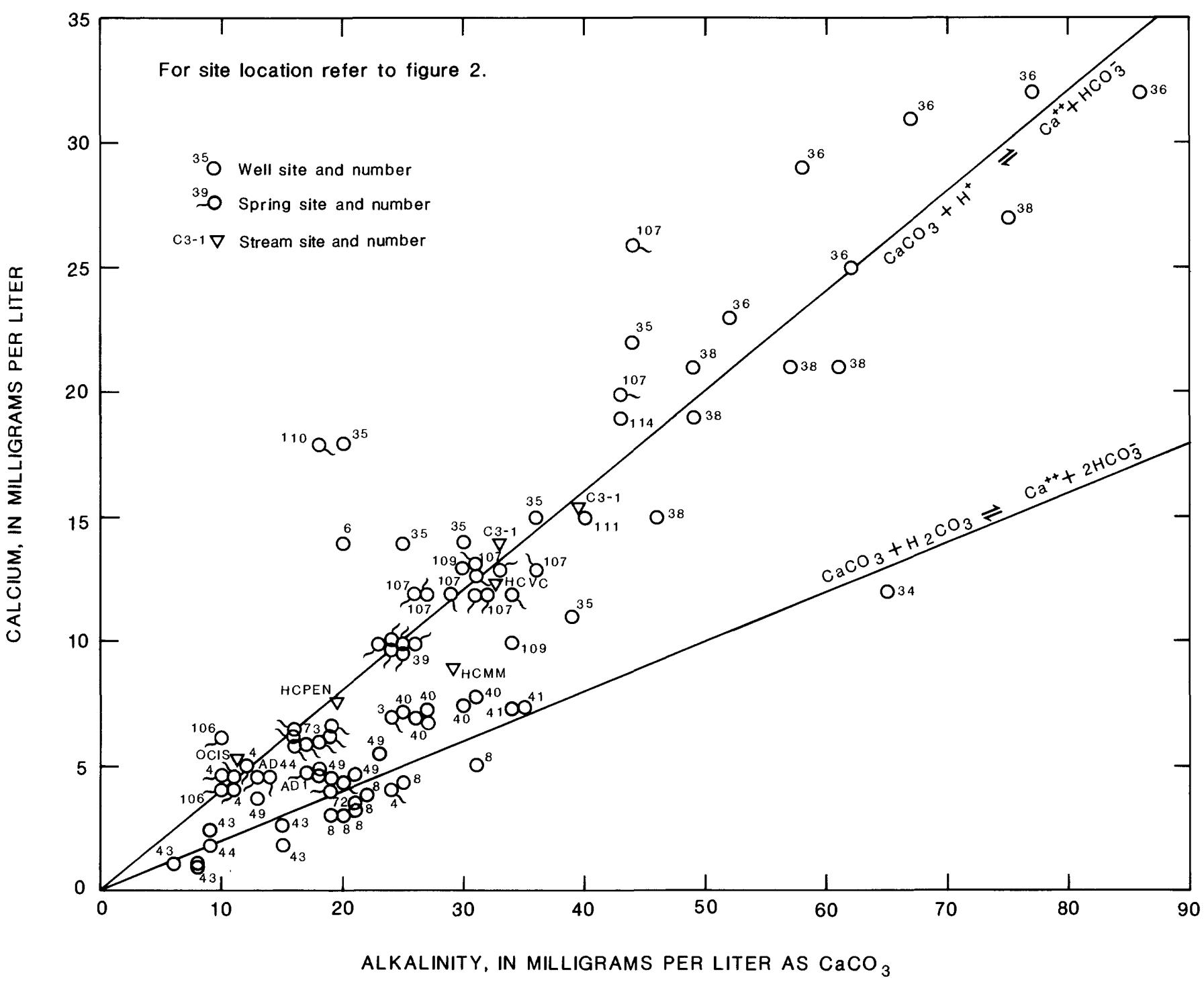

Figure 15. Relationship of calcium concentration to alkalinity for all sites sampled. 
the Adirondack Shelter spring (AD 44), the Owens Creek campground springs (BD 72, BD 73), and one sample from the "Ike Smith" springs (BD 3).

Type III water, which has low chloride (less than $3 \mathrm{mg} / \mathrm{L}$ ) and high nitrite plus nitrate concentrations (greater than $2.0 \mathrm{mg} / \mathrm{L}$, as $\mathrm{N}$ ) is represented by samples from one spring located near Owens Creek campground (BD 73). It is a poorly developed spring that flows from beneath a loose pile of rocks. Mud and debris was stirred up whenever this spring was sampled.

Type IV water (chloride greater than $3 \mathrm{mg} / \mathrm{L}$ and nitrite plus nitrate $<0.3 \mathrm{mg} / \mathrm{L}$ ) includes samples from the Blue Blazes well (BD 34) near the Visitors Center, and one sample each from Camp Misty Mount (BD 7, BD 8) and Poplar Grove. Stream samples are from Hunting Creek tributaries near Camp Misty Mount (HCMM) and from the Visitors Center (HCVC). The Visitors Center sites are adjacent to roads that are salted during the winter. The Camp Misty Mount and Poplar Grove sites may be receiving salt from roads located higher up on Catoctin Mountain at Camp 3.

The high-chloride, intermediate nitrite plus nitrate water (type V) is affected by animal waste and possibly road salt from Camp 3, Park Central Road, Route 77 , and Foxville-Deerfield Road. This type includes samples from the "Ike Smith" springs (BD 4, BD 106), Walnut spring (BD 110), Hunting Creek near Camp Peniel (HCPEN), Owens Creek near Owens Creek campground (OCCG), Owens Creek tributary near the "Ike Smith" springs (OCIS), from a stream flowing out from Camp 3 (C 3-1), and from a well located near Camp Greentop (BD 6).

High chloride and high nitrite plus nitrate concentrations (type VI) indicate probable contamination by road salt and human septic waste. The chloride concentrations measured in this type are approximately 2 to 30 times greater than those measured in type I. Nitrite plus nitrate concentrations are 7 to 18 times greater. This type includes two stream samples from near Camp 3 (C 3-1, C 3-2), all of the well and spring samples from Staff Quarters No. 5 (BD 107, BD 114), and from the Camp Round Meadow area (BD 35, BD 36, BD 38, BD 108, and BD 109); it also includes BD 39, which is located downhill from both Camp Round Meadow and from a section of Park Central Road that is salted in the winter.

Figure 17 shows the chloride and nitrite plus nitrate content of water at park sites. Wells at Camp Peniel, Camp Misty Mount, and "Jim Brown" have the best quality of water in the study area (type I). The poorest quality of water is at Camp Round Meadow and Staff Quarters No. 5 (type VI). The water-quality study (1979-81) of streams, wells, springs, and the septic lagoons at Camp Round Meadow by the Ecological Services Laboratory, National Park Servize, indicated that water from streams and wells are of good quality and suitable for human consumption and most other uses in the park. The results of a study by Huth Engineers and R. E. Wright Associates (1981) suggested possible low-level septic contamination of the Camp Round Meadow production wells. The chloride and nitrite plus nitrate data in figure 16 support the conclusions of both studies. 


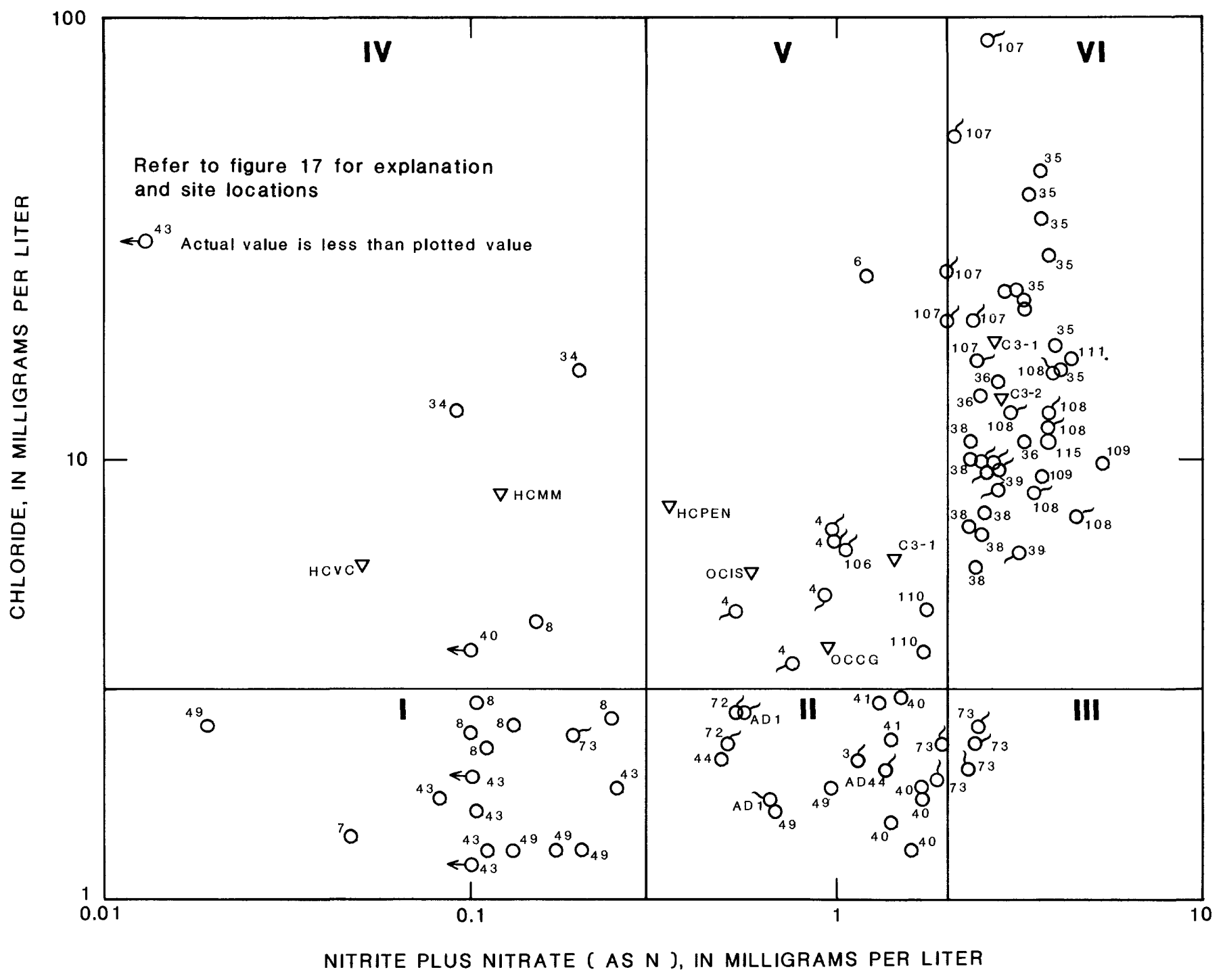

Figure 16. Relationship of chloride concentration to nitrite plus nitrate concentrations for all sites sampled, and corresponding water types. 

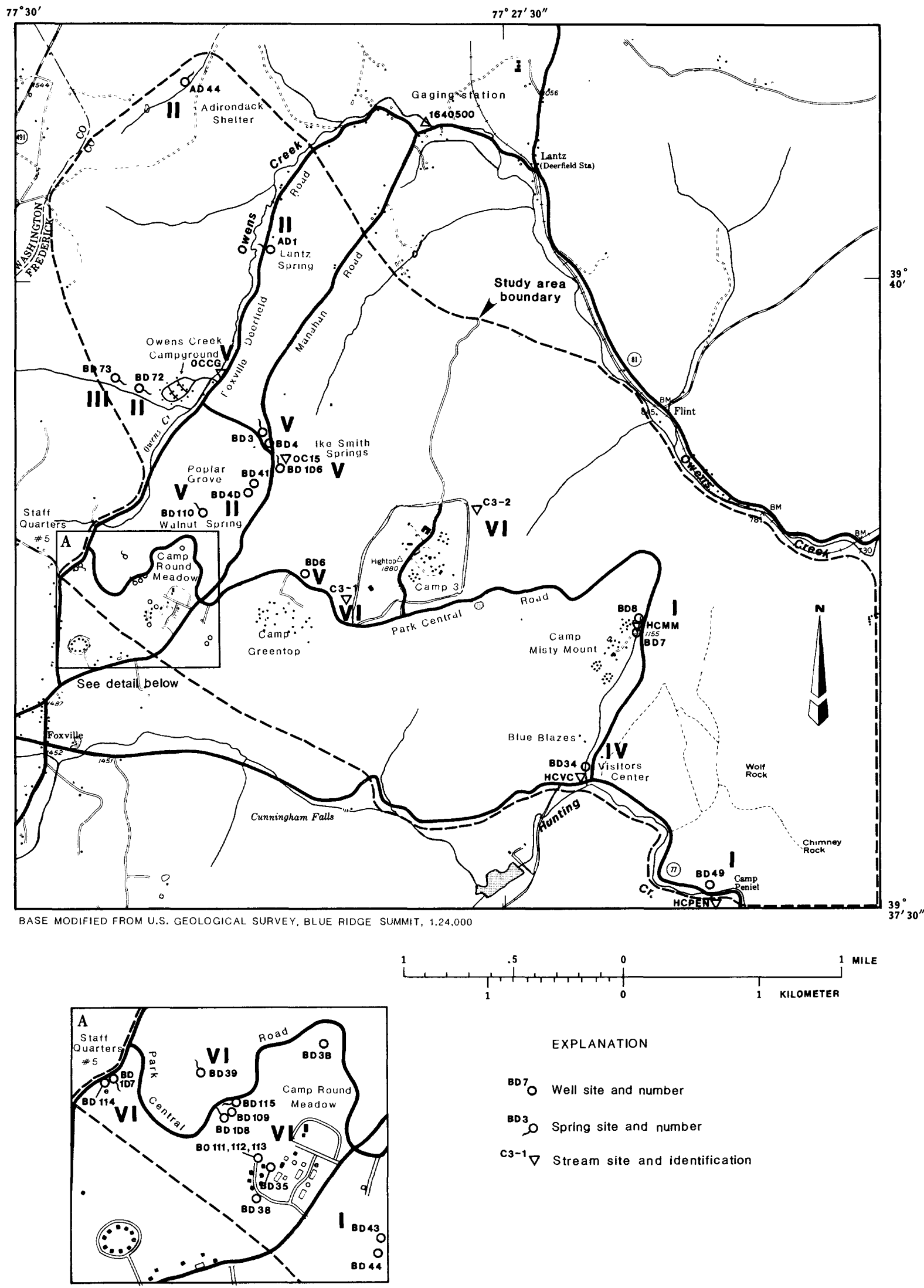

EXPLANATION

${ }^{807}$ Well site and number

${ }^{80}{ }^{\circ}$ Spring site and number

${ }^{c 3-1} \nabla$ Stream site and identification

Figure 17. Generalized classification of sampling sites in terms of the six chloride and nitrate water types. 


\section{Bacteria}

Fecal streptococcus (FS), fecal coliform (FC), and total coliform (TC) bacteria were used in this study as indicator organisms for fecal contamination. These bacteria reside in the intestines of warm-blooded animals. Their appearance in sampled water, therefore, suggests fecal contamination.

Employing the membrane-filter method, plate counts of FS, FC, and TC bacteria were used to compare concentration densities throughout the park (table 2). Results indicate an absence of FC in all sampled wells. Concentrations of less than five colonies per 100 millileters of sample were observed in most of the springs, with the exception of springs near Camp Round Meadow (BD 39, BD 108, and BD 115), Staff Quarters No. 5 (BD 107), and Owens Creek Campground (BD 73), where elevated concentrations occurred.

Fecal streptococcus were observed in all wells and springs sampled throughout the park. Concentrations exceeding 100 colonies per 100 millileters of sample were observed in Camp Round Meadow wells BD 35 and BD 36, "Jim Brown" wel1 BD 43, and springs near Camp Round Meadow (BD 108 and BD 115), and Owens Creek Campground (BD 73).

Further tests were performed to determine if the FS found in the park water was indeed FS bacteria (table 3 ). Results confirmed the presence of FS bacteria in springs BD 73, BD 107, BD 108, and BD 115. Apparent FS colonies found in Camp Round Meadow wells BD 35 and BD 36 were determined to be nonstreptococcus species.

The presence of FC and confirmed FS indicates that there is fecal contamination present in Owens Creek spring Bd 73, Staff Quarters No. 5 spring BD 107, and Camp Round Meadow springs BD 108 and BD 115. Owens Creek spring Bd 73 had a very low yield which made it difficult to pump without introducing mud into the sample. The addition of soil bacteria into the water sample may have altered its bacteria concentration. A cow pasture is located uphill from Staff Quarters No. 5 spring BD 107, which may influence its water quality. Camp Round Meadow springs BD 108 and BD 115 are located directly downgradient from the camp's sewage lagoon and sand filters, potential point sources of bacteria from human waste. This is supported by the presence of three seeps in the sand filter areas. The effluent from these seeps was percolating into the ground within a few feet of the seepage areas. Seepage leaching from sand filter 3 ( fig. 5) was tested for fecal contamination at a point just before it percolated into the ground and its FS, FC, and TC bacteria concentrations were high.

In summary, bacteria results indicate that springs in the Camp Round Meadow area are being contaminated by septic wastes. Other more remote wells and springs derive lower concentrations of fecal bacteria from animal waste and decaying plant and animal matter. 
Table 3.--Results of fecal streptococcus confirmation tests

\begin{tabular}{|c|c|c|c|c|c|c|}
\hline Station & $\begin{array}{c}\text { Sample } \\
\text { No. }\end{array}$ & Date & \multirow{2}{*}{$\begin{array}{c}\begin{array}{c}\text { Catalase } \\
(+/-)\end{array} \\
+\end{array}$} & \multirow[t]{2}{*}{$\begin{array}{r}\text { Gram } \\
\text { Stain } \\
(+/-) \\
\end{array}$} & $\begin{array}{c}\text { Confirmation } \\
\text { test results } \\
(+/-)\end{array}$ & \multirow{2}{*}{$\begin{array}{r}\begin{array}{r}\text { Gelatin } \\
\text { liqui- } \\
\text { faction } \\
(+/-)\end{array} \\
-\end{array}$} \\
\hline $\mathrm{Bd} \quad 35$ & L 30-1-7 & $5 / 08 / 84$ & & & Non $\mathbf{S}$ & \\
\hline Bd 35 & L39-1-8 & do. & + & & Non $\mathrm{S}$ & \\
\hline $\mathrm{Bd} \quad 35$ & L40-1-9 & do. & + & & Non $S$ & - \\
\hline Bd 35 & L27-1-10 & do. & + & & Non $S$ & \\
\hline $\mathrm{Bd} \quad 35$ & L25-1-11 & do. & + & & Non $\mathbf{S}$ & - \\
\hline $\mathrm{Bd} \quad 35$ & $510-1-12$ & do. & + & & Non $S$ & \\
\hline $\mathrm{Bd} \quad 35$ & s32-1-13 & do. & + & & Non $\mathrm{S}$ & - \\
\hline Bd 35 & s11-1-14 & do. & + & & Non $s$ & \\
\hline $\mathrm{Bd} \quad 35$ & S34-1-15 & do. & + & & Non $\mathrm{S}$ & - \\
\hline $\mathrm{Bd} \quad 35$ & M36-1-16 & do. & + & & Non $\mathbf{S}$ & \\
\hline Bd 35 & M23-1-17 & do. & + & & Non $S$ & - \\
\hline Bd 35 & M18-1-18 & do. & + & & Non $\mathrm{S}$ & \\
\hline $\mathrm{Bd} \quad 35$ & M38-1-19 & do. & + & & Non $\mathrm{S}$ & - \\
\hline Bd 36 & M2-1-20 & do. & + & & Non $\mathrm{S}$ & \\
\hline $\mathrm{Bd} \quad 36$ & $54-1-21$ & do. & + & & Non $S$ & - \\
\hline Bd 108 & $2-11 A 142-2$ & $5 / 16 / 84$ & + & + & Non $S$ & \\
\hline Bd 108 & $2-11-14$ & do. & + & + & Non $S$ & \\
\hline Bd 108 & $4-13-12$ & do. & - & + & EFS & - \\
\hline Bd 108 & $3-12-13$ & do. & - & + & EFS & - \\
\hline Bd 107 & $53-15-3$ & do. & - & + & GFS & - \\
\hline Bd 107 & $51-14-4$ & do. & - & + & GFS & - \\
\hline Bd 107 & L4-17-5 & do. & - & + & Non $S$ & - \\
\hline Bd 107 & L $2-16-6$ & do. & - & + & GFS & - \\
\hline $\mathrm{Bd} 115$ & $5-15$ & do. & - & + & GFS & - \\
\hline Bd 115 & $6-16$ & do. & - & + & GFS & - \\
\hline $\mathrm{Bd} 115$ & $7-17$ & do. & - & + & EFS & - \\
\hline Bd 115 & $8-18$ & do. & - & + & Non $S$ & - \\
\hline & Control & $5 / 04 / 84$ & - & + & EFS & - \\
\hline & FS-L Control & do. & - & + & EFS & + \\
\hline & FS Control & $5 / 08 / 84$ & - & + & EFS & - \\
\hline & FS-L Control & do. & - & + & EFS & + \\
\hline & FS-L Control & do. & - & + & EFS & + \\
\hline & FS-L Control & do. & - & + & EFS & + \\
\hline & FS Control & do. & - & + & EFS & - \\
\hline & FS Control & do. & - & + & EFS & - \\
\hline
\end{tabular}

FS - Streptococcus faecalis

FS-L - Streptococcus faecalis liquifaciens

EFS - Excellent streptococcus faecalis

GFS - Good streptococcus faecalis

Non S - Non-streptoccus species 


\section{SUMMARY}

Catoctin Mountain National Park, located in the Blue Ridge physiographic province of central Maryland, is characterized by local topographic relief of up to $1,080 \mathrm{ft}$, annual precipitation of $44 \mathrm{in.}$, and well-drained, stony loam soils. The park area, which is underlain by weathered and fractured metamorphic rocks, consists mostly of forested land with several camp areas and roads. Potential sources of ground-water contamination in the park are from septic systems and road salt.

The park aquifer consists of regolith that overlies bedrock. The ground-water system is recharged by precipitation that infiltrates the soil and percolates to the water table. The water table ranges from land surface at springs and streams to about $70 \mathrm{ft}$ below land surface on ridges; it usually is in the regolith except on ridges. Ground water flows in the regolith and in fractures in bedrock and discharges to nearby streams. About 57 percent of total annual precipitation leaves the park area as streamflow; about 56 percent of the annual streamflow is contributed by ground water that discharges to streams as base flow.

Pumping rates of 45 to $60 \mathrm{gal} / \mathrm{min}$ can be sustained at wells in Camp Round Meadow and Staff Quarters No. 5 for periods of several hours with drawdowns of 40 to $50 \mathrm{ft}$. The effects of pumping can be observed in wells at least as far as $400 \mathrm{ft}$ from pumping wells.

Water-quality samples from wells, springs, and streams indicate that acid precipitation may be affecting the quality of ground water in the park area. Concentrations of chloride and nitrite plus nitrate, and bacterial counts indicate that wells and springs in the Camp Round Meadow and Staff Quarters No. 5 areas are being contaminated by septic waste and road salt, but to a relatively minor extent. Other, more remote wells and springs have fecal bacteria and nitrite plus nitrate concentrations that probably come from animal waste and decaying plant and animal matter. Some wells and springs away from main camp areas have chloride concentrations that indicate contamination from nearby salted roads. Finally, ground water in the Camp Misty Mount, Camp Peniel, and "Jim Brown" areas has low natural concentrations of chloride, nitrite plus nitrate, and bacteria. None of the samples exceeded U.S. Environmental Protection Agency drinking-water standards for chloride or nitrite plus nitrate (as N). 


\section{REFERENCES CITED}

American Public Health Association, 1976, Standard methods for the examination of water and wastewater, 14 th edition, Washington, D.C., 1193 p.

Fauth, J. L., 1977, Geologic map of the Catoctin Furnace and Blue Ridge Summit quadrangles, Maryland: Maryland Geological Survey, scale $1: 24000$, 1 sheet.

Geldreich, E. E., 1970, Applying bacteriological parameters to recreational water quality: Journal of the American Water Works Association, v. 62, no. 2 , p. $113-120$.

Greeson, P. E., Ehlke, T. A., Irwin, G. A., Lium, B. W., Slack, K. V., editors, 1977, Methods for collection and analysis of aquatic biological and microbiological samples: U. S. Geological Survey Techniques of Water-Resources Investigations, Book 5, Chapter A4, 332 p.

Huth Engineers, Inc., and R. E. Wright Associates, Inc., 1981, Hydrogeology study, Catoctin Mountain Park, Maryland: Huth Engineers, Inc., Lancaster, Pennsylvania, 17604, 82 p.

Katz, B. G., Bricker, 0. P., and Kennedy, M. M., 1985, Geochemical massbalance relationships for selected ions in precipitation and stream water, Catoctin Mountains, Maryland: American Journal of Science, v. 285, p. 931-962.

Linsley, R. K., Kohler, M. A., and Paulhus, J. L. H., 1958, Hydrology for engineers, McGraw-Hill Book Company, New York, 340 p.

Mates, A., 1983, Rapid differentiation of Streptococcus fecalis variety liquificiens from other fecal streptocci in water testing: Journal of the Water Pollution Control Federation, v. 55, no. 9, p. 1211-1213.

Matthews, E. D., 1960, Soil survey of Frederick County, Maryland: U.S. Department of Agriculture, Soil Conservation Service, 144 p.

Munse11 Color, 1975, Munsell soil color charts, Baltimore, Maryland.

Skougstad, M. W., Fishman, M. J., Friedman, L. C., Erdmann, D. E., Duncan, S. S., editors, 1979, Methods for determination of inorganic substances in water and fluvial sediments: U.S. Geological Survey Techniques of Water-Resources Investigations, Book 5, Chapter Al, 626 p.

U.S. Department of Commerce, 1968, Climatic atlas of the United States, p. 48,53 , and 56 .

U.S. Environmental Protection Agency, 1976, National interim primary drinking water regulations: EPA-570/9-76-003, 159 p.

Vokes, H. E., and Edwards, Jonathan Jr., 1957, [1974], Geography and geology of Maryland: Maryland Geological Survey, Bulletin 19, p. 68, 72. 